\title{
Arazi Kullanım Kararlarının Dere Sistemleri Üzerinde Fiziki Etkisinin Analizi ve Kentsel Yaşama Yansıması: İstanbul'da Su Baskını, Sel ve Taşkın Risk Değerlendirmesi
}

\author{
The Analyses of the Physical Effect of Land Use Decisions on Stream \\ Systems and its Reflection on Urban Life: The Risk Evaluation of \\ Flood and Overflow in İstanbul
}

\author{
(D) Hülya Dinç \\ İstanbul Teknik Üniversitesi, Şehir ve Bölge Planlama Anabilim Dalı, İstanbul
}

\section{ÖZ}

Dünya sel ve kuraklıkla ilgili küresel alarmdadır. Dünya Araştırma Enstitüsü, 2030 yılında dünya nüfusunun yarııının su sıkıntısı yaşayacağııı; sellerin etkisinin 3 kat artacağını, 54 milyon insanın etkileneceğini vurgulamaktadır. Fiziki çevreyi kontrolde tutan en önemli faktör dere sistemleri ve havzalarıdır. Bu sürece dere havza sistemleri hazır mı? Dere (drenaj) havzasının dere sistemi, kollarıyla yüzey üstü/altı kaynaklarını, yağış sularını toplar ve kara sistemine suyu dağıtarak boşalıılar. Doğal havzasında dengede olan hidrolik sistemler, hatalı arazi kararlarıyla doğal morfolojisini, havza akış yönlerini kaybetmesi, artan yapısal yüzeyler vb. etkenlerle drenaj yoğunluğunu değiştirmesi, taşkınları sıklaştırmaktadır; değişen iklim faktörü ile de şiddetini artırmaktadır. Son yıllarda sıklaşan taşkınlar, nehir/dere ekosistemlerinin fiziki yapısını ve üzerinde bulunduğu arazi kullanım kararları ile ilişkisinin araştırılmasını, bulguların çevresel risk açısından değerlendirilmesini şehir, ulusal ve uluslararası ölçeklerde gündeme taşımaktadır. Ülkede bütüncül su hukukunun bulunmaması, idari problemler, su ekosistemini içme suyu havza alanı olan ve olmayan şeklinde parçalayan yaklaşımlar, koruma aleyhinde yasalar, vb. ile dere sistemleri (su kaynakları) korunmamakta, sürdürülebilirliği devam ettirilmemektir. Bu araştırmada, İstanbul'da içme suyu havza alanı dışında bırakılan yaklaşı $2740 \mathrm{~km}^{2}$ yüzölçümlü alanda, açık havza konumunda olan (Karadeniz, Marmara Denizi, Boğaziçi, Haliç ve Göllerine dökülen) 168 akar dere havzasına ve havzada bulunan yaklaşı 3344 km uzunluğunda dere sistemlerine odaklanılmıştır. Bulgular, boy kesitine göre değerlendirildiğinde, derelerin \%73'ü doğal yapısını koruduğu, \%27'si doğasına aykırı fiziki değişime uğrayarak yeni formlara dönüştüğünü göstermektedir. Dere sistemlerinin $\% 79$ 'u kırsal alandan geçtiği ve doğal yapısını koruduğu; \%2l'i ise kentsel alanda bulunduğu, çeşitli müdahaleler ile fiziksel yapısının değiştiği fakat kaybolmadığı, üzerindeki arazi kararlarından etkilendiği ve dere koruma

\section{ABSTRACT}

The World Resources Institute reported that nearly half of the world population will experience water shortage in 2030; the effects of floods will be tripled globally. Drought and floods threaten several cities all around the country, including Istanbul. The most important factors that control the physical environment are stream systems and their basins. Are the stream basin systems ready for this process? Hydraulic system balanced in its natural basin has lost its natural morphology and direction of overland flowing because of land decisions given wrongly by the authorities. This situation shows that it is essential to analyze the physical structure of stream/river ecosystems and land use decisions on the urban, national, and international scales. The lack of integrated water law, management problems, and the laws against the protection of stream systems have caused the problem. The present study focuses on the $3344 \mathrm{~km}$ long stream systems that are in the basins of 168 running streams and in nearly $2740 \mathrm{~km} 2$ outside drinking water basin in Istanbul. The findings show that $73 \%$ of the stream systems have protected their natural structure, $27 \%$ have transformed its natural structure, and $79 \%$ have protected their natural structure in rural areas according to longitude. Of the stream systems, $21 \%$ have transformed its natural structure in urban areas because of various interventions, but they have not disappeared, they have been affected by land use decisions, and stream protective zones have been deforced. Based on the stream basin scale, 
bantlarının işgal edildiği anlaşıımışır. Dere sistemleri havza ölçeğinde değerlendirildiğinde, araştırma sahasının \%64'ü (I08 dere havzası) fiziksel değişimden az/çok etkilenerek havzasında sel, taşkın, kuraklık ve diğer çevresel riskleri oluşturmaktadır. Araştırma, problemlerin kentin geneline (\%5l'ine) yayıldığııı göstermektedir. Bulgular, derelerin birbirlerinden bağımsız birimler olmadığııı ve önerilecek yasal düzenlemelerin dereleri havza sistemleri ölçeğinde değerlendirilmesi gerektiğini; araştırılan derelerin açık havza sistemi olması nedeniyle uluslararası öneme sahip olduğunu göstermektedir. Doğal dere sistemlerini korumak, sürdürülebilirliğini sağlamak, riskleri yönetmek, faydaya çevirmek için, yasal, kurumsal, teknik problemleri ortadan kaldıracak devlet kontrolünde ivedilikle bütüncül su hukuku, havza ölçeğinde bütünleşik havza planlaması ve havza yönetimi, sürdürülebilir dere restorasyon programına ihtiyaç vardır.

Anahtar sözcükler: Arazi kullanım; dere kıyı ekosistemi; İstanbul dere havzaları; kuraklık; sel.
$64 \%$ of the region have been affected because of the transformation, and some environmental risk, such as floods and drought, have been spread to the whole city. The findings show that streams are not independent from each other; laws must evaluate streams on the basin system scale, and streams are important internationally as they are open basin systems. Integrated basin planning and management, sustainable stream restoration program, and holistic water law controlled by the government are essential to find solutions to legal, technical, and corporate problems; protect natural stream systems; maintain their sustainability; and overcome the risks.

Keywords: Land use; Istanbul stream basins; buffer; drought; flood.

\section{Giriş}

Su ekosisteminde dere sistemleri, havza ölçeğinde kolları ve doğal kıyı ekosistemi ile havza hidrolojisini dengeleyen; yer üstü kaynaklarını, yağış sularını toplayan ve boşaltan doğal drenaj havzası; yaşamın su kaynakları ve biyolojik rezerv alanlarıdır (Hollis (1975); Stabler (1985); Booth (I99I) vd.).

Kentsel ve kırsal alanlarda hatalı yerleşim kararları ve çevre kullanım alışkanlıklarının yarattığı baskı ile dere sistemleri kirletilmekte; fiziksel yapıları değiştirilmektedir. Bu değişim sel, kuraklık vd. çevresel riskleri beraberinde getirmektedir.

Öyle ki son dönemlerde, dünyada sel ve kuraklıkla ilgili küresel alarma geçilmiş; iklim değişimi nedeniyle, su sıkıntısı yaşanacağının, sellerin etkisinin 3 kat artacağının dikkati çekilmektedir (Url-10, Url-I I, Url-I2).

Doig, A. (20I5), küresel ısınma nedeniyle, “..2060 yılı itibariyle bir milyar kişinin sel felaketi riski altındaki şehirlerde yaşayacağını; büyük kıyı kentlerinde yaşayanların özellikle risk altında olduğunu" açıklamaktadır (Url 10). Dünya araştırma enstitüsü (Url-I3), dünya genelinde her yıl ortalama olarak yaklaşık 21 milyon insanın nehir taşkınlarından etkilendiğini; iklim değişikliği ve sosyo-ekonomik gelişme nedeniyle bu sayının 2030 yılında 54 milyona yükselebileceği konusunda uyarmaktadır.

Türkiye'de son dönemlerde yağışlar, İstanbul, Ankara, Zonguldak, Antalya, Mersin, Rize, İzmir vd. birçok şehirlerinde sel ve taşkınlar oluşturarak maddi/manevi zararlar vermiştir. Dünya örneklerinde bu deneyimler, ulusal ders çıkarttırmış, drenaj havzası olan dere yataklarının ciddiyetle planlanmasını ve yönetimini uygulama programlarına aldırtmıştır.

Birleşmiş Milletler, Dünya Sağıı Örgütü’nün raporları, küresel sel ve taşkınların artmasının dışında, ayrıca kuraklığa da dikkat çekmektedir. Bu raporlarda, 2017 yılında 2, I milyar insanın temiz içme suyuna erişimden yoksun olduğunu; İklim değişikliği ile 2030 yılında dünya nüfusunun yaklaşık yarısının su sıkıntısı yaşayacağı açıklanmaktadır [(Url-6; UN-Habitat (20I3); United Nations. (1996)].

Bir ülkenin su zengini sayılabilmesi için, kişi başına düşen yıllık su miktarı en az 8000-10.000 $\mathrm{m}^{3}$ olmalıdır. Günümüzde bu değerin Batı Avrupa ortalaması $5.000 \mathrm{~m}^{3}$, Güney Amerika ortalaması $23.000 \mathrm{~m}^{3}$; Dünya ortalaması. $7.600 \mathrm{~m}^{3}$, Türkiye'de ise $1430 \mathrm{~m}^{3}$ 'tür. Bu rakam, Türkiye'nin su stresi çeken ülke olduğunu; 2030 yılında nüfusun 100 milyona ulaşmasıyla, kişi başına düşen su miktarı $1000 \mathrm{~m}^{3}$ 'e düşeceği ve Türkiye'nin su fakiri ülkeler arasına gireceğini göstermektedir (Url-7, Url-6; UN-Habitat, 2013).

Su, sadece insanoğlunun yaşam kaynağı olmadığına göre, yeryüzünde doğal yaşamın sürdürülebilirliği düşünüldüğünde, susuzluğun yaratacağı kuraklık tehlikesinin etkilerinin de büyük boyutta olacaktır. Su kıtlığı hem doğal hem de insan kaynaklı bir olgudur. Dünya üzerinde milyar insana yetecek kadar tatlı su bulunsa da, bu oran coğrafi olarak yeryüzüne eşit dağılmamakta, büyük bölümü israf edilmekte, kirletilmekte ve sürdürülemez şekilde yönetilmektedir.

Önemli su kaynaklarından ve aynı zamanda doğal drenaj sistemi olan dere sistemleri ve havzalarının doğal morfolojisi çeşitli müdahalelerle bozulmakta ve/veya kaybedilmektedir. Dönüşen ve/veya kaybolan her dere sistemi, çevre için sel, taşkın ve aynı zamanda bölge için kuraklık vb. yaşamsal tehditler oluşturmakta; yaşama sunduğu fırsatların kaybedilmesine neden olmaktadır. Kriken vd. (20I0), Verniers, vd (20I3), Scarr, (20।4), Bölen ve diğ. (2009)'nin yapmış oldukları araştırmalarda, kontrolsüz, plan dışı, parçacıl ve düşük maliyetli bir biçimde büyüyen kentlerde en çok yapılaşmış alan çevresindeki tarım ve orman alanların, su havzaların, dere ve vadi yatakların etkilendiğine dikkat çekmişlerdir. 
Sel/taşkın, kuraklık gibi çevresel risklerin önlenmesi, iklim değişiminin kontrol altında tutulması, dere sistemlerinin havza ölçeğinde havza morfolojisinin doğal yapısının korunması ve sürdürülebilirliğinin sağlanması ile mümkündür. Doğal dere sistemlerinin sunduğu fırsatları korumak; değişmesiyle meydana gelen çevresel riskleri önlemek için dere sistemlerinin fiziki durumunu, üzerindeki arazi kullanımla ilişkisinin havza ölçeğinde araştırılması makale ile gündeme taşınmıştır.

Makale, dere sistemlerinin fiziki değişimi ve üzerinde olduğu kent makroformunun belirleyicisi olan arazi kullanım kararlarının bulgularını, analizini, konuya ilişkin kavramsal yaklaşımları, araştırma metodolojisini, sel, taşkın ve beraberinde getirdiği diğer riskler açısından değerlendirmeyi ve öneri yaklaşımını kapsamaktadır.

Biyom içinde su ekosisteminde yeraltı yerüstü kaynakları ayrılmaz bütünlükteyken; Türkiye'de genel tespitler, derelerin yasal, yönetsel, planlama ve uygulama yaklaşımlarıyla içme suyu havzasında olan ve olmayan gibi su ekosistemini parçalayan yaklaşımlarla ayrıldığını göstermektedir. İçme suyu havza alanı dışındaki dereleri koruyan yasal, yönetsel çerçevenin bulunmaması; mevcut yasal yönetsel koruma yaklaşımlarının kısıtlı ve parçacıl olması alan seçiminde belirleyici olmuştur.

Araştırma, yaklaşık 5.400 km² yüzölçüme sahip İstanbul ilinin içme suyu havza alanı dışında kalan, yaklaşık 2740 kilometrekare alanda (İstanbul'un yaklaşık \%5 I büyüklüğünde) açık havza konumunda olan, Karadeniz, Marmara Denizi, Boğaziçi, Haliç ve Göllere (Küçükçekmece, Büyükçekmece) dökülen, akar dere sistemlerinde gerçekleştirilmiştir.

Makalenin hazırlanmasında ulusal ve uluslararası yazılı ve görsel kaynaklar, gözleme dayalı ön tespitler, mevcut basılı, dijital halihazır haritalar ve raporlardan yararlanılmıştır. Çalışmada İstanbul'un kentsel gelişiminde, "kaybolan dere hatlarının durumunu tespit edebilmek ve sonraki çalışmalarda ölçek oluşturması için" elde edilebilen ilk sayısal 2007 onaylı I/I.000 ölçekli halihazır haritaların kullanılması tercih edilmiştir.

Yapılan araştırmada, İstanbul'da açık havza konumunda 168 adet dere havzası ve bu havzalarda akar dere konumunda yaklaşık 3.344 km. uzunluğunda dere sistemi tespit edilmiştir.

Tespit edilen dere sistemleri boy kesitine göre değerlendirildiğinde, derelerin \%73’ü (2.443 km) doğal yapısını koruduğu; \%27'si (90l km) ıslah edilerek fiziki yapısını dönüştürdüğü saptanmıştır.

Derelerin üzerinden geçtiği arazi kullanım yapısı ise; \%79'u (264l km.) kırsal alanda, \%2l’i (703 km) kentsel alanda kalmaktadır. Fiziki değişimin olduğu dere sistemlerinin üzerinde olduğu arazi yapısı aynı zamanda dere koruma zonları çeşitli yapısal ögelerle (kamu binası, konut, sanayi, aktif rekreasyon vb.) işgal altında olduğunu göstermektedir.

Dere sistemleri havza ölçeğinde (drenaj havzası) değerlendirildiğinde, \%36'sı (60 adet dere havzası) membadan mansaba kadar doğal yapısını koruduğu; \%64'ü çeşitli nedenlerden dolayı kısmen ve/veya tamamen fiziki değişime uğradığı tespit edilmiştir. Dere sistemindeki bu değişimler havza geneline sel, taşkın vb. çevresel problemler olarak yansımaktadır. Bu problemler İstanbul'un geneline yayılmış durumdadır. Araştırılan derelerin açık havza konumunda olması nedeniyle, problemlerin etkisi uluslararası ölçeğe taşınmaktadır.

Analizler, derelerin kırsal alanda doğal yapısını koruduğu, fiziki değişime uğramadığını; kentsel alanlarda ise çeşitli müdahalelerle fiziksel değişime uğradığını hatta kaybolduğunu göstermiştir. Değişim sonrasında yeni formların oluştuğu görülmektedir.

Hatalı arazi kararların neden olduğu değişimin şeklini belirleyen en somut etken, dere sistemlerinin en kesitinde yapılan mühendislik ve tasarım yaklaşımıdır. Yapılan araştırmada, dere sistemlerinin en kesitinin doğal yapısının dışında, kapalı ve açık kesit sistem olarak değişim gösterdiği; boy kesitinde ise doğal sistem, kapalı kesit sistem ve açık kesit sistem olarak 3 temel form ve bunların kombinasyonları ile yeni tipolojiler oluşturduğu tespit edilmiştir.

Bu şekilde meydana gelen yeni dere tipolojileri derelerin fiziki yapısı ile arazi kullanım kararları arasındaki ilişkiyi kanıtlamaktadır. Kavramsal araştırmalar, dere sistemlerinin fiziki yapısını değiştirmesiyle ve hatta kaybolmasıyla havzanın drenaj yoğunluğunun değiştiği, taşkın riski taşıdığı/taşıyacağı, aynı zamanda bölgede kuraklık etkisinin artacağı vurgulamaktadır. Ayrıca işgal altında olan taşkın alanlarında olası deprem riski taşıdığı; kentsel ve kırsal yaşama sunduğu fırsatları ortadan kaldırdığı; bölge, ülke ve kıtalar arası ekolojik koridorları kesintiye uğratarak biyolojik zincirin sürekliliğine zarar verdiği, kent ve kır arasındaki bağı kopardığı; doğa-toplum ve doğa-ekonomi çatışması ile doğal yaşam kaynaklarını olumsuz etkilediği açıklanmaktadır.

Dere sistemlerinde kıyı ekosistemini kaybederek fiziki dönüşümüne sebep olan problemlerin başında, koruyucu kapsamIı su hukukunun olmaması, havza ölçeğinde plan kararlarının alınmaması, doğa merkezli olmayan arazi kararları, yetkide çeşitlilik, disiplinler arası ilişkinin kurulmaması, ıslah altında hatalı mühendislik ve tasarım yaklaşımlarıdır.

Araştırmalar bu problemlerin, geçmişten günümüze tüm zamanların hatalı arazi kararların sonucu olduğunu göstermektedir (Şekill).

Çevresel riskleri kontrol altına almak ve küresel iklim değişimini 

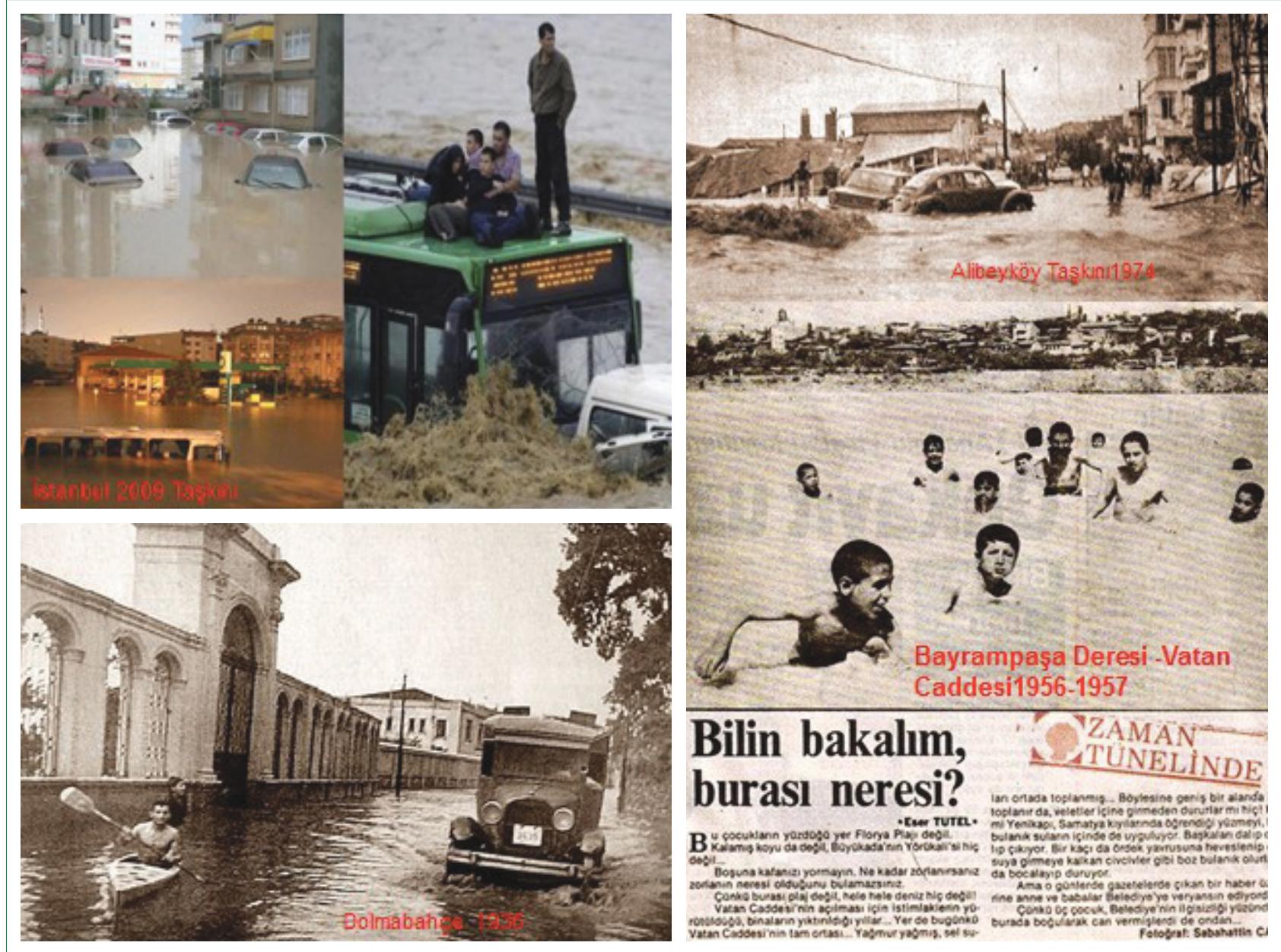

Şekil I. İstanbul'da çeşitli dönemlerde meydana gelen taşkınlar.

yönetmek demek; dirençli kentleri oluşturmak ve aynı zamanda çevre sağlık yaşam kalitesini yükseltmektir; ekoloji ekonomi sürdürülebilirliği sağlamaktır. Bu nedenle, doğal yapısını koruyan dere sistemleri havza ölçeğinde ivedilikle koruma altına alınmaııdır. Fiziki değişime uğrayan/dönüşen dere sistemleri doğasına uygun sürdürülebilir havza bazlı dere restorasyonu programı ile geri kazanılmalı ve çeşitli yöntemlerle durum faydaya çevrilmelidir. Dirençli kentler için, dere sistemleri gibi doğal dinamiklerin kentleşmeyle sürdürülebilirliği sağlanmalı; kentsel baskıdan, hatalı arazi kararlarından koruyacak yasal, teknik, kurumsal, toplumsal önlemleri içerecek bütüncül yeni bir planlama yaklaşımı gündeme taşınmalıdır. Bu kapsamda devlet kontrolünde bütüncül su hukuku, havza ölçeğinde bütünleşik havza planlama ve havza yönetimi, dere havza sistemlerinin doğasına uygun potansiyellerini ortaya çıkaracak disiplinler arası doğa yaklaşımlı yeni politikaların üretilmesine ihtiyaç vardır. İstanbul'daki dere sistemlerinde yapılan bu araştırmanın bulguları ve analiz sonuçları problemleri somut olarak aşağıda ortaya koymakta; ilgili teorik araştırmalar konunun ulusal ve uluslararası önemini vurgulamakta; sürecin ivedilikle gündeme taşınarak planlamada disiplinler arası koordinasyonla çözüm önerisi beklediğini göstermektedir.

\section{Kavramsal Yaklaşım}

Dere sistemleriyle ilgili daha önce yapılmış uluslararası teorik ve saha çalışmaları araştırıldığında; su ekosisteminde bir sistemler bütünü olan dere sistemi ve havzası nedir? Doğal bileşenlerinden olan kıyı ekosistemi ne ifade etmektedir? Drenaj yoğunluğu ve drenaj havzası nedir? Dere sistemleriyle aralarında nasıl ilişki bulunmaktadır? Doğal varlığı ile çevreye sunduğu katkılar nedir? Dere sisteminin sel, taşkın, kuraklıkla ilişkisi nedir? Arazi kullanım kararlarının dere sistemleriyle ilişkisi nasıldır? Dünyada su hukuku dere sistemlerine nasıl yaklaşmaktadır? vb. soruların yanıtları alanlarında uzman araştırmacılar tarafından verilmeye çalışıımışıı. Planlama yaklaşımı içinde önemli olan bu teorik yaklaşımlar, aynı zamanda İstanbul'un dere sistemlerinde yapılan araştırma bulgularının değerlendirmesinin çerçevesini de oluşturmaktadır.

Dere, su ayırım çizgisiyle ayrılan topografya yardımıyla yüzey üstü, yüzey altı su kaynaklarını ve yağı̧ sularını yüzey üstü taşınmasına imkan veren, akar ve kuru dere yan kollarıyla birlikte tek çıkış yapan sistemdir. 
Doğal dere sistemi, kıyı sucul yaşamı (kıyı ekosistemi) ile birlikte bulunur. Kıyı ekosistemi zonu olarak tanımlanan bu bölge, dere veya akarsu boyunca kendine has doğal bitki örtüsüne (vejetasyon) sahip fauna ve flora habitat alanlarıdır (Wenger ve Fowler, 2000). Bu zon (kıyı ekosistem zonu=riparian zon) su kalitesine, erozyon önleme fonksiyonuna, hidrolojik dengenin sağlanmasına, biyoçeşitliliğin korunmasına, biyolojik zincirin sürdürülebilirliğine, vb fonksiyonlara hizmet etmektedir (Wood, Armitage, 1997; Hardesty, Kuhns, 1998; Kauark, Leitte, 1999; Wenger, Fowler, 2000; Naiman, Bilby, Bisson, 2000).

Wenger ve Fowler, (2000)'a göre su kıyısı ekosistemini (koruma zonu) korunması, çeşitli çevresel, ekonomik, sosyal faydaları sağlamaktır. Bu nedenle dere veya akarsu sistemlerini su yolu boyunca doğal bitki örtüsüyle (vejetasyon) düşünülmesi gerektiğini açıklamışlardır.

Dere sistemlerinin yaşama sunduğu ölçülebilen ve ölçülemeyen çok yönlü katkıları kıyı ekosistemi ile birlikte gerçekleşmektedir (Horton 1945, Woods, 1966; Campbell, 197I; Odum, 1974; Ogden, Lacey, Foster, 1975, Richard ve Wood, 1985; Wood, Armitage, 1997; Wenger, Fowler, 2000; Hardesty, Kuhns, 1998; Naiman, Bilby, Bisson, 2000; Kauark, Leitte, vd. 1999; City of Flagstaff, 2009 vd.).

Dere kıyılarındaki sucul habitatlar için, su kıyısı zonu olarak ayrılması suyun kalitesini artırmaktadır (Erman, Costick ve Beckwitt, 1996).

Nabhan (1985), ise derelerin sırtlarıyla birlikte doğal hava koridorları ve kentin hava sirkülasyonunu düzenleyen doğal ekolojik koridorlar olduğunu açıklamaktadır.

Doğal yapısını koruyan her dere sistemi habitat alanı ve su kaynağıdır (Gordon, John, Daniel 1966; Corbett ve Lynch, 1985; Mayer, Franti, Mortensen, 1997). Biyolojik zincirin kurulduğu doğal yaşamın dengelendiği (King, vd. (20I2), Campbell (I97I)); kentli için rekreatif ihtiyaçların karşılandığı alanlardır (Field, Lee ve Martinson 1985). Toplum ve çevre sağlığını iyileştirmekte; kültürel eğitim ve sosyalleşme; kent ve kentlilik bilincinin gelişmesini sağlamaktadır. Kendine has topografyası vb. doğal özellikleri ile kente panorama, vista zenginliği sunan, kentsel donatıları ayıran doğal tampon alanlardır (Hynes, 1970). Kaynak olarak ise kendi iç değeri dışında çevresine ve kent ekonomisine katkı sunan önemli kamusal alanlardır (Jhan ve Trefethen, 1972; Correll, Lillydahl ve Stingell, 1978; Richard ve Wood, 1985; Burgess, Harrison, Limb, 1998; Luttik, 2000; Lindsey, Man, Payton, vd., 2003; Gao ve Asami, 2005; The trust for public land, 2013 vd.).

Dere havzası (drenaj havzası) ise, bir dere sistemini oluşturan su ayırım çizgisiyle birlikte topografyanın sağladığı vadi taban ve yamaçlarının bütünü ile kapladığı yüzey alanıdır (Dunne ve Leopold, 1978).
Havzayı oluşturan ana mecra (boğaz) ve ona bağlı bulunan kolların havzaya düşen yağış sularını toplama ve/veya boşaltabilme yeteneği vardır (Pallard, Castellarin ve Montanari, 2009).

Drenaj yoğunluğu; derenin boyu ile havza büyüklüğü arasındaki ilişkidir (derenin etki boyunu) (Kahya, Erkek, Ağıralioğlu, 2006). Kuru ve akar kollarıyla birlikte dere yataklarının doğal fiziki yapısı akış büyüklüğünü (drenaj yoğunluğunu) belirlemektedir. Drenaj yoğunluğu dere uzunluğuyla doğru orantılı olan bu dere hatları havzanın su sistemlerini toplarken, sulama ihtiyaçlarını da karşılamaktadır (Wooding, 1966). Havzanın drenaj yoğunluğu ne kadar yüksekse o havzadaki drenaj ağının yağış sularını çevreye zarar vermeden akıtma özelliğine sahiptir (Horton, 1945; Carlston, 1963; Melton, 1957; Carlston, 1963).

Bu alanda çalışma yapan araştırmacılardan; Horton (1945)'de erozyonla drenaj yoğunluğunun ilişkili olduğunu; en iyi drenajın havza içerisinde derenin dallanma sayısı olduğunu belirtmiştir.

Drenaj yoğunluğunun, Melton (1957) yağışlarla (iklimle); Turner and Skibitzke (1952); Rove (1963); Woodyer ve Brookfield (1966); Skinner vd. (1985) bitki örtüsünün kaldırılmasıyla ilişkili olduğunu; Rodriguez, Iturbe ve Escobar ( 1982) drenajın iklimin dışında havzanın jeomorfoloji, hidroloji ile ilişkisi olduğunu; Moglen, Eltahir ve Bras (1998) sadece iklim değişikliği ile değil iklimle doğrudan ilişkili olduğunu; Kobold ve Seselj (2005)'de havza şekli ile ilişkisini; Pallard, Castellarin ve Montanari (2009) drenaj yoğunluğu ile taşkın arasında ilişkisini kanıtlamışlardır.

Yapılan bilimsel araştırmalar, bir dere havzasının, akar ve kuru dere kollarıyla birlikte hidrolojik sistemden daha fazlası olduğunu göstermektedir (Corbett, vd. 1985; Gordon, John, Daniel 1966; Mayer, Franti, Mortensen, 1997). Dere sistemleri fiziksel çevre kalitesine, ekonomiye, yaşam sağlığına vb. alanlara sundukları katkıları ile kentsel yaşam kalitesi göstergeleri arasında gösterilmektedir (Türkiye, UN, 1996; Türkiye, Ulusal Rapor ve Eylem Planı, 1996; Dülger Türkoğlu, Bölen, Baran, Marans, 2008; Türkoğlu, Bölen, Korça, Terzi, 20I I,Jhonson, Carothers, 1982; Jhonson ve Lowe, 1985; Erman, Costick, ve Beckwitt, 1996; Wenger, Fowler, 2000; Mayer, Reynolds, Canfield, 2005; Xia ve Xin, 2010),

Yapılan araştırmalar drenaj yoğunluğunun; iklim faktörü; hidrolojik özellikler, toprak yapısı ve toprak derinliği; topografik yapı, rölyef özellikleri ve ilişkisi, eğim derecesi, bakı; bitki örtüsü, infiltirasyon; yapılaşma vb. etkenlerle de yakından ilişkili olduğunu; her havzanın hidrolojik özelliklerinin farklı olup; mikroklima, edafik, topografik, vejetasyon vb. faktörlerin bağlı yerelin drenaj yoğunluklarının değişebileceğini ve dolayısıyla risk eşiklerinin de değişebileceğini göstermektedir.

Ayrıca araştırmalar, havzanın drenaj yoğunluğunun kontrolü 
için her havza için güvenlik eşiklerinin belirlenmesi; kayıtlarının tutulması; izlenmesi gerektiği; sağlıklı çevre yaşamı için drenaj yoğunluğunun dengesinin önemli olduğu; bu eşiklerin aşıldığında sel, taşkın, erozyon vb. problemleri oluşturacağını; çevre yaşam sağlığını tehdit edeceğini göstermektedir.

Taşkın ise teorik olarak, derelerin muhtelif nedenlerle doğal drenaj yoğunluğunu değiştirerek yatağından taşması, çevresindeki arazilere, yerleşim yerlerine, alt yapı tesislerine ve canlılara zarar vermesi, etki bölgesinde normalin üzerinde sosyo-ekonomik faaliyeti kesintiye uğratacak ölçüde bir akış büyüklügünü oluşturması şeklinde ifade edilmektedir (Url-9).

Araştırmalarda, su baskınları, sel ve taşkın sebeplerinin araştırılmasını, derenin havza sistemiyle havza ölçeğinde değerlendirilmesi gerektiği vurgulanmaktadır. Ayrıca, sel ve taşkınların, Tucker ve Bras, (2010) arazi eğimi, havza morfolojisi ile; Zhang, Wang (20I3); Gregory ve Walling (20I0) havza akışı, drenaj yoğunluğu, erozyonun etkili olduğunu açıklamaktadırlar. Kauark, Leitte, vd.(1999) vd. araştırmacılar, kentleşmiş alanlarda ve/veya yeni kentleşme ile dere sistemlerindeki fiziki dönüşümler, kaybolan hatlar (kuru ve akar kollarda) nedeniyle hidrolik yapıların yetersiz kalması; hidrolik kanalları tıkayan tortu vd. etkenler ile sel, taşkın erozyonların meydana geldiğini açıklamışlardır (Turner and Skibitzke (1952); Rowe (1963); Sauer, Thomas, Stricker ve Wilson (1983); Skinner, Smith, Dodd, Rodgers (1985); Naiman, Bilby, Bisson (2000); Booth, Karr, Schauman, vd. (2004); Platt (2006); Zhang, Wang, Li vd. (20I3) vd. araştırmacılar).

Taşkın sebeplerini Anderson (1970), May, Horner, Karr, ve arkadaşları (20I4), vd araştırmacılar teknik, kurumsal ve yasal problemler olduğu hususunda birleşmektedir.

Arazi kullanım kararlarının derelerle ilişkili araştırmalarda; derelerin sunduğu doğal ve fiziki işlevler göz önünde bulundurulmadan gerçekleşen kontrolsüz, plansız arazi kullanımlarının havzanın doğal morfolojisini, sınırlarını, büyüklüğünü ve hidrolojisini değiştirerek drenaj yoğunluğunu etkilediği; havzada geçirimsiz yüzeylerin artması ile doğal drenaj işlevlerini kaybedeceği vurgulanmaktadır. Dale, Brown, vd., (2000), Booth, Karr, vd., (2004); Platt (2006) vd. araştırmalarında kent içerisinde derelerin fiziki işlevleri göz önünde bulundurulmadan, havzası içerisinde her arazi kararı ve uygulamasında, drenaj yoğunluğunun doğal yapı içerisinde işleyişindeki dengenin etkileneceğini; havza içinde ve ilişkili alt havzalarında sel ve taşkın oluşturacağını belirtmektedirler. Yüzey akışını kentleşmeyle araştıran Hollis ( 1975), havza yüzeyinin \%5'i sert yüzeyle kaplandığında yıllık ve daha uzun yağışlarda yüzey akışların normal olduğunu; \%5 oran aşıldığında en küçük yüzey akışın 10 kat etkisinin arttığını; havzanın \%30'u sert yüzeyle kaplandığında ise 100 yıllık yağışlarda yüzeysel akışın \%30 oranında hacimsel olarak arttığını belirtmektedir.
Doğayı merkezine almayan kentleşme ile dere yatakları ve kıyı ekosistemleri bozularak doğal yapı değişmektedir. Zaman içerisinde suyun kalitesi etkilenerek kirlilik, susuzluk ve kuraklık oluşmakta; doğal habitatlar kaybolmakta; biyolojik çeşitlilik tehdit edilmekte/kaybolmaktadır (Moring, Garman, Mullen, (1985); Scott, Shuttleworth, vd., (2000).

Mikro ölçekteki davranış, değişim; makro ölçekteki sitemleri etkileyerek biyolojik zinciri koparmakta, ilişkide olduğu peyzaj ve ekolojik bölgeleri vd. üst sistemleri yani yerküreyi etkilemektedir.

Horton (1945); Campbell (197I); Odum (1974); Kriken ve diğ. (20I0); Vörösmarty, vd.,(20I0); Allan, (20I2); Verniers ve diğ. (20I3); Scarr, (20I4) vd. araştırmacılar, doğaya öncelik vermeyen arazi kullanım kararları ve uygulamaların, derelerin doğal yapısını değiştirerek kaybolmasına, yaşam kalitesinin düşmesine neden olduğunu; kent sağlığını tehdit ettiğini vurgulamaktadırlar.

\section{Dünyada Dere/Nehir Sistemlerine Planlama Yaklaşımı}

Dere/nehir sistemlerindeki araştırmalar, 20. Yüzyılın ilk dönemlerinde akarsu organizmalarının biyolojileri üzerine odaklanırken, 1950'li yıllardan sonra su ekosistemini bütüncül ele alan yaklaşımlar hakim olmuştur (Shelford, Eddy (1929). 1980 yılından itibaren dere sistemi su havzasının birimi olduğu; dere sistemlerinin havza içinde zamansal ve mekansal perspektifle çeşitli bileşenlerle entegre halinde gerçekleşmektedir (Hynes, 1970; Minshall ve diğerleri, 1985). 1980- I 990 yıllardan 21. yüzyıla kadar ilgili meslek alanlarının oluşması; disiplinlerarası doğa yaklaşımının gelişmesi; coğrafi bilgi sistem(CBS) analizlerinin araştırmalara katılmasıyla çalışmalar derinleşmiştir. Günümüzde su ekosistemlerinde disiplinlerarası ilişki ile derelerin sürekliliğinin sağlanması (RCC=biyoto birleşimlerinde fiziksel geçiş ve bağlantı noktalarında tüm akarsu/dere sistemlerinin sürekli olarak gözlenmesidir.) hızlı bir gelişme kaydetmektedir.

Avrupa'da dere/nehir sistemlerinde yapılan araştırmalar, yağışların toplanarak derelere ve derelerden nehir, göl ve denizlere doğru akışların kesintisiz ulaşımı kendine has habitatıyla birlikte sağlandığını, su döngüsünün izlendiğini göstermektedir. Dere/nehir sistemlerinin makro ölçekte (havza sistemleri içinde) araştırılmakta; coğrafyanın iklim ile binlerce yıldır oluşturduğu doğal morfolojisine uyumlu alınan kırsal ve kentsel arazi kararlarında doğal yaşam merkezli planlama ile çok bileşenli disiplinin koordinasyonu sağlandığında yağış kontrollerinin kolaylaştığı görülmektedir.

Avrupa genelinde kırsal ve kentsel alanlarda bozulan/zarar gören dere ekosistemlerin tespit edilmekte; "Doğal” mü- 
hendislik çözüm teknikleri ile kendi doğal yapısına yeniden kuracak mühendislik yaklaşımları ile dere/nehir restorasyonu gerçekleştirilmektedir. Planlama, uygulama, denetim hizmetleri devlet ve yerel yönetimlerce gerçekleştirilmekte; korumaya, sivil toplum kuruluşları dahil edilerek; uygulamaya teşvik edilmektedir. Ayrıca, nehir/dere restorasyonları devlet kontrolünde kamu kuruluşu tarafından birçok nehir restorasyonu faaliyetleri ile ilgili bilgilerin ve iyi uygulamaların paylaşılması için bir veri tabanı politikası geliştirilmiş, bu politika için dere/ nehir havzası plancıları, uygulayıcıları arasında yerelden ulusa ve uluslararası ölçeğe net work iletişim ağı ile gerçekleştirilmektedir.

Dere/nehir restorasyonlarında, dere sistemleri kendini idame ettirene kadar bölge halkıyla birlikte denetim ve gözlem altında tutulmaktadır. Kontrollü yerleşim alanlarında ve doğal morfolojiye aykırı bir müdahale var ise havza ölçeğinde mühendislik hesapları ve doğal yapının göstergelerin gözden geçirilerek yenilendiğinde nehir/dere sistemlerinin restorasyonlarının büyük çaba ve maliyet gerektirmediği vurgulanmaktadır.

Bozulan kıyı ekosistemlerin, kapanan derelerin, nehir, deniz ekosistemlerin restorasyon ile doğal yapısı yeniden kazanılarak ekolojik koridorlar güçlendirilerek, nehir/dere sistemlerinin iklim değişikliğine uyumuna yardımcı olması sağlanmış; nehir restorasyonu ile seli yönetmeyi başarmışlar ve ayrıca depolama yöntemi ile taşkınları tarım, bahçecilik, aktif rekreasyon alanları vb. amaçlarla kullanarak kendi menfaatlerine çevirmişlerdir. (Fausch vd., 2002; Cushing, Cummins, Minshall, vd., 2006).

Avrupa'da su ekosisteminde, sürdürülebilir nehir/dere havza sistemleri için, çeşitli idari düzeylerde uluslararası imzalanan sözleşmelerden yararlanılmaktadır. Örneğin; Habitat, Su Çerçeve Direktifi vb. havza bazlı yerel ölçekte her nehir ve/veya derenin restorasyonu için yaşam koşullarının yaratılması ve geliştirilmesi için destek alarak bölgenin ekolojik durumu iyileştirilmektedir.

Dünyada su hukuku araştırıldığında, nehirler etrafındaki yaşamla eski çağ medeniyetlerine kadar uzanmaktadır. Nehir havza kavramı; sınır aşan suların kullanımının ilkesel yaklaşımları ortaçağ Roma Hukukuna dayanmaktadır. Nehirlerde nehir havzalarının gerek su hareketinin gerekse kirlenmeye karşı gözetimde tutulması ve birlik yönetiminin getirilmesi de ortaçă̆ dönemlerine uzanmaktadır. Nehir sularının korunması, izlenmesi, yönetilmesi kapsamında süreç içerisinde çözüme yönelik gecikmelere neden olan süreçler yaşanmışta olsa; iklim değişikliğinin su üzerinde yaratacağı kuraklık ve kıtlık endişesi sınır aşan sularda ulusları ortak zeminde yasal, yönetsel, izleme ve planlama da bir araya getirmiştir. 1965 de Su yönetimi nehir havza yönetimi ile birleştirilmiştir (Mitchell, 2005; Mitchell ve Gardner, 1983; Teclaff, 1996; Teclaff, 1994; Mayer, vd,. 1997). 1990'lı yıllarda su ekosistemini korumak için su ekosistem restorasyonu; 1992 Dublin "Su ve Sürdürülebilir Kalkınma" Bildirgesi'nde su kaynaklarının etkin yönetimi ile BütünselEntegre Havza yönetimi; 1992 Rio de Janerio'da gerçekleşen Birleşmiş Milletler Çevre ve Kalkınma Konferansı Gündem 2 I'de suya dayalı entegre su kaynakları yönetimi ekosistemi; entegre havza yönetimi kavramı içerisinde havza veya alt havza düzeylerinde yeraltı ve yerüstü sularını birleştirilmektedir. Suyu bütüncül ele alarak, daha odaklı ve/veya kapsamlı sistem perspektifi getirilmektedir. 1970'li yıllardan itibaren Avrupa Birliği su politikaları gelişmekte; 1990'lı yılların ikinci yarısından itibaren çalışmalara başlanan 2000/60 sayılı Su Çerçeve Direktifi 23 Ekim 2000 tarihinde 2010 yılında su hakkı BM 2 I.yy gerçekleri nehir havza kavramını ihtiyatlıık ilkesinde kendi içinde sürdürmektedir.

Günümüzde; ülkelerin kendi iç hukukunda su hukuku ve yönetiminin gelişmesi sağlanmıştır. Analistler ve planlamacılar arasında kıyı ve sınır sorunlarında karşılaşılan konuları en aza indirebilmek için; Entegre Su Kaynakları Yönetimi (IWRM) yaklaşımı görüşü benimsenmiştir.

Su hukukun tarihsel süreci nehir havzalarını kapsamış olsa da yapılan araştırmalar, su yönetimini nehir/dere havza yönetimi ile aynı kavramda birleştirmektedir.

Dünyada su hukuku, dere sistemlerinin su ekosisteminden ayrılmaz bir bütün olduğunu ve birleştirici su hukukunun bulunması gerekliliğinin, dere sistemi ve onun ayrılmaz parçası olan dere kıyı zonlarının havza ölçeğinde korunmasına yönelik yapılan planlamada bütünleşik havza planlama ve havza yönetiminin önemli olduğunun, kamusal yapılanma ile kullanıcı bilincinin ve yönetişim anlayışı geliştirilerek yerel ve ulusal gündeme ivedilikle taşınması gerektiğinin altını çizmektedir (Gatewood ve arkadaşları (1950); Rowe (1963); Bosch ve Hewlett (1982); Moring, Garman, vd.(1985); Teclaff, L.A. (1996); Teclaff L.A, Teclaff E. (1996); Allan, Erickson, ve Fay (1997); Turner, ve arkadaşları (199I), Brown (2000); Steiner (200I); Palmer, Bernhardt, vd. (2005), Mitchell (2005); Yeang (2006), Weeler (2008); Stromberg, Tellman (2009); Kriken, Enquist, Rapaport (2010), Xia, Zhu, vd. (20I0); Hermosa vd. arkadaşları (20II), vd. dir).

Türkiye'de su hukukunun yasal çerçevesi 20I I yılından itibaren taslak halinde bulunmaktadır. Dere sistemleriyle ilgili uluslararası, ulusal ve yerel mevcut yasal uygulama araçları aşağıda özetlenmiştir.

\section{Dere Sistemleriyle İlgili Yasal Çerçeve}

Türkiye'de dere sistemlerinin korunması, izlenmesi, yönetilmesi ile ilgili yapılan yasal, planlama, uygulama araçları, uluslararası, ulusal çerçevede ve İstanbul yerelinde olmak üzere 3 alt başlık altında araştırılmıştır. 
a) Uluslararası su hukukunda dere sistemleri araştırıldığında, dereleri ve dere kıyı ekosistemlerini koruma amaçlı Türkiye'nin de imzaladığı sözleşmelerinin olduğu görülmektedir. Bunlardan önemli olanları; 3958 Kanun ile 28.12.1993 tarihli Ramsar Sözleşmesi, 23.I I.2002 tarihli Avrupa Birliği Su Çerçeve Direktifi, 27 Temmuz 2003 tarih ve 25।8I sayılı Resmî Gazete'de yayınlanan 488I sayılı kanun Avrupa Peyzaj Sözleşmesi, 1997 yılında uygulamaya giren Gündem 21,vd.dir.

Örneğin; Ramsar Sözleşmesi'nin amacı, ekolojik olarak sulak alanlara bağımlı olan kuşları, korumak olsa da aynı zamanda derelerin tespitinin yapılmasını, listelenmesini ve korunmasını sağlatmaktır. "Doğal veya yapay, devamlı veya geçici, suları durgun ve akıntılı, tatlı, acı veya tuzlu denizlerin gel-git hareketlerinin çekilme devresinde 6 metreyi geçmeyen derinlikleri kapsayan bütün sular, bataklık, sazlık ve türbiyerler sulak alanlardır." şeklinde tanımlayarak, 6 m'ye kadar akar ve kuru dere yataklarının da tespit edilerek listelenmesini ve korunmasını şart koşar.

Avrupa Birliği Su Çerçeve Direktifi sözleşmesi ise iyi su kalitesini hedeflemekte; bütüncül bir yaklaşım öngörmektedir. Planlamada Entegre (Bütünleşik) Havza Yönetimini gündeme getirmiştir.

Avrupa Peyzaj Sözleşmesi, Avrupa'daki tüm peyzajların envanterinin çıkarılması; korunması, yönetim ve planlanmasına yeni bir düzenleme getirmektedir.

Gündem 2 I Eylem Planı ile de "Biyolojik Çeşitlilik" ve "iklim Değişikliği”, ekosistemin korunması ve geliştirilmesinde, su, doğal kaynak vd.nin önemini vurgu yapmaktadır.

\section{b) Ulusal su hukukunda dere sistemleri araştırıldığın-} da; öncelikle su kaynaklarının korunması ve denetimi, TC. Anayasa'nın 56. Maddesi: A bendi'ne göre "herkes sağlıklı ve dengeli bir çevrede yaşama hakkına sahiptir" ifadesi ile sağıı ve çevrenin korunması gereği anayasa hükmüne bağlanmıştır.

Fakat yasal çerçevede günümüzde, Türkiye'de derelerin korunması, planlanması, işletilmesi ile ilgili yetki, sınır, içerik ayırmaksızın bütünü içeren yasası bulunmamaktadır Ancak derelere gönderme yapan yasa, yönetmelikler vardır. Su kaynakları ve derelere atıf yapan yasa ve yönetmeliklerin bazıları; Orman ve Su İşleri Bakanlığının yetkisinde; 645/20 I I sayılı Orman ve Su İşleri Teşkilat Kanunu, 167/1960 sayılı Yer Altı Suları Koruma Kanunu, 2872/1983 sayılı Çevre Kanunu, 5216 sayılı Büyükşehir Belediyesi Kanunu, 28483/20I2-Yüzeysel Su Kalitesi Yönetimi Yönetmeliği, 28444/2012; Su havzalarının korunması ve yönetim planlarının hazırlanması hakkında yönetmelik, 28910/2014 Yüzeysel sular ve yeraltı sularının izlenmesine dair yönetmelik, 2705।/2008 sayılı Çevre Düzeni Planlarına dair yönetmelik: (Url-8), vb.'dir.
Ulusal yasal uygulama araçlarında dere sistemlerini değerlendirdiğimizde, İçme suyu havza alanlarını korumaya yönelik yasa ve yönetmelik planlar içerisinde bir ara hüküm olarak geçmektedir. İçme suyu havza alanı dışındaki dereleri ise koruma kapsamına alınmamaktadır. Bu dere sistemleri nehir ölçeğinin dışında bırakılarak ilgili yasa ve yönetmeliklerde bulunmamaktadır.

c) İstanbul'da dere sistemleri ile ilgili yasal uygulama araçları araştırıldığında, derelerin, korunmasından İstanbul Büyükşehir Belediyesi, ISKI ve yerel yönetimler sorumludur.

Derelere atıfta bulunarak planlamayı ve uygulamayı etkileyen yasa ve yönetmelikler 2705 I sayılı Çevre Düzeni Planı, ISKI İçme Suyu Havza Yönetmeliği, DSi yönetmeliği ve 5216 sayılı Büyükşehir Belediyesi Kanunudur. Derelerle ilgili uygulamada en etkin yönetmelik ISKi İçmesuyu Havzalar Yönetmeliği, DSi 6200 Devlet Sular İdaresi, Yerel yönetimlerin görev ve yetkileridir.

İçme suyu havza niteliğinde olmayan dereleri koruyan yaklaşım ise sadece İstanbul ili için ISKI VE DSI yönetmeliklerinde derelere yaklaşma mesafesiyle planlamaya dair yapılanma koşulları ile gönderme yapan yönetmeliklerdir. Bu yaklaşım derelerin ve kıyı ekosisteminin kendine has doğal ve fiziki yapısını göz ardı edilerek getirilmiş standart yaklaşım olup, uygulamalarda yetersiz kalmaktadır. Dere sistemleri üzerinde etkin olan bu iki yönetmeliğe göre,

- 2560 sayılı ISKİ İçme Suyu Havza Yönetmeliği: Yönetmeliğin ilk çıkış tarihi 20.1 I.198I yılından 2014 tarihine kadar araştırıldığında; dereleri koruyan ve yapılanmayı sınırlayan planlama koşulları, derelerin her iki tarafı için yapı yaklaşma mesafesi tanımlanır. Yapı yaklaşma mesafesi (koruma bandı); 1984 yılında derenin her iki tarafinda 100 metredir. 02.01.20I 3 tarihli karar ile 10 metreye daraltılmıştır. Yetkili olduğu İstanbul'da Boğaziçi'ne dökülen derelerdir. Uygulamada iSKI'nin İstanbul Büyük Şehir Belediyesinin (IBB) alt birimi olması, Büyükşehir Belediyesi'nin derelerle ilgili görev ve sorumluluklarıla birleşince İstanbul genelinde íSKi yönetmeliği uygulama görmektedir.

- 6200 sayılı Devlet Sular İdaresi(DSi) yönetmeliği: Dere koruma bandı, derenin her 2 tarafında 35 metredir. DSi'nin yetkin olduğu alanlardaki derelerde geçerlidir. Bu dereler Karadeniz, Marmara, Haliç ve Göllere dökülen derelerdir.

İstanbul'da derelerin korunması ve denetimine ilişkin yapılan araştırmalar, bütüncül bir yaklaşım içinde geliştirilmiş mevzuatın bulunmadığını, derelerin birden fazla kurum ve kuruluşun yetki, görev alanlarına girdiğini göstermektedir. Bu nedenle; bir dereyi yer aldığı havzasının özelliklerine göre ilgili yasa, idari alan ve yönetmeliklere göre değerlendirmek gerekmektedir. 


\section{İstanbul'da Dere Sistemlerinin Karşılaştı̆̆ı Problemler}

Dere sistemlerinde sel, taşkın sebeplerine neden olan problemler yasal problemler, kurumsal problemler, teknik kullanımlar, insan faktörü olarak özetlenebilir.

\section{a) Yasal problemler}

Uluslararası sözleşmelerin uygulamaya geçmemesi; ulusal ölçekte dere sistemlerini kapsayan bütüncül su yasasının olmaması, koruyucu yasa ve yönetmeliklerin havza ölçeğinde yaklaşılmaması, kıyı ekosistemini tanımlamaması, derelere standart koruma mesafesi getirilmesi, hatalı arazi kararları ve doğal merkezli olmayan planlama yaklaşımları, soyut biyolojik zincir, ekolojik koridorlar, ekosistem vb. tanımlamalar, işgalcilerin baskılarından koruyacak yönetim ve kontrol eksiklikleri; koruma aleyhine değişen yönetmelikler, koruma aleyhinde yasa, uygulama görmeyen yönetmelik, raporlar (ÇED, vb.) vd'dır.

\section{i-Koruma aleyhine değişen yönetmeliklerden bazıları}

- Derelerin koruma bandındaki alanlara ait yoğunluk değerleri 16.10.2009 tarih, I979 sayılı IBB Meclis kararlı meri plan hazırlanırken genel yoğunluk hesabına katılmamış, bununla beraber II.02.2010 tarih, 5I4 sayılı IBB Meclis kararı ile değiştirilen meri plan ile dere kadastral sınırından itibaren sağı sollu 100 m olarak bırakılan bu alanlara, dere yapı yaklaşma mesafesi dışındaki diğer alanlarda kullanımak üzere, 23.01.20II tarihli yönetmelik doğrultusunda yapılaşma hakkı verilmiş; 02.01.2013 tarihinde değişiklik yapılan ISKi İçmesuyu havzaları yönetmeliği ile yerleşilebilir (yoğunluk hesabına dahil edilen) alanlar durumuna getirilmiştir.

- 2560 sayılı íSKi İçme Suyu Havza Yönetmeliğinin yapı yaklaşma mesafesi (koruma bandı); 1984 yılında derenin her iki tarafında 100 metredir. 02.01.2013 tarihli karar ile 10 metreye daraltılması, kuru dereler dere statüsünden çıkartılması vd.dir.

- Çeşitli tarihlerde çıkartılan imar aflarıdır. 2018 tarihinde çıkan "imar barışı" altında getirilen aflar dere taşkın alanlarını yerleşim izni verilerek çevresel risklerin yaşanmasının önü açılmış, geri dönüşü zor, yıkıcı etkilerin yaşanacağını göstermektedir.

\section{ii-Planlama sisteminde derelerin durumu}

İstanbul için ana plan kararı sayılan I/I00.000 ölçekli İl Çevre Düzeni planında, İçme Suyu havza alanı dışındaki derelerin korunması ve gelişmesine ilişkin planlama ve yönetim planı önerisi bulunmamaktadır (IBB, 2009). İçme suyu havzasını besleyen derelere ve büyük sistem ekolojik koridorların korunması dikkate alınmış fakat geçmişten günümüze İstanbul'un doğal morfolojisini de belirleyen içme suyu havza alanı dışında kalan dere sistemlerini koruyan planlanmaya rastlanmamıştır. İstanbul il Çevre Düzeni Raporunda “...Bölgenin hidrolojisi önemli özelliklere sahip değildir. Büyük akarsu sistemi bulunmamaktadır....." (IÇDP, 2009) geçen ifade; doğal sistemin bütünlüğü içerisinde nehir sistemlerini besleyen birer doğal ekolojik koridorlar olan dere sistemleriyle ilişkisi göz ardı edildiğini göstermektedir.

b) Kurumsal problemler; en temel problem idari ve yetkide çeşitliliktir. Planlamanın ve özellikle uzun vadeli planlamanın eksikliği; bütünleşik planlama, yönetimin olmaması ve kentsel gelişmenin doğal sistemler üzerindeki kontrolünün eksikliği; bu ilişkilerde yürütülen ölçümlerde göstergelerin eksikliği; vd. etkenler olarak gösterilmektedir. Özellikle son yıllarda taşkınlarda yaşanan maddi manevi kayıp ve afetlerden dolayı sorumluluklara yönelik açılan davalar araştırıldığında, ruhsatlıruhsatsız yapılarda idari sorumlulukların dağılımının önemli olduğu anlaşılmakta; uygulama takiplerinin yetki karmaşasından kaynaklandığı Danıştay 6.Daire Esas No:2009/I9I, Karar No: 20 I I/5 I7 alınan kararlarda görülmektedir.

Yetkili kurumların derelerin mansabının konumuna göre farklılık göstermesi, birden fazla ilçe sınırından geçen derelerin plan yapma ve işletme yetkisinin birbirinden bağımsız farklı yerel yönetimler tarafından yapılması gibi derelerin parçacıl olarak planlanması, denetlenmesi, uygulama görmesi; dere havzasının coğrafi konumuna bağlı mevzuatlarda farklılıkların bulunması (Boğaziçi İmar Yönetmeliği, vd.); arazi kullanım kararının derelerin fiziki yapısında belirleyici olan maden, turizm vb. öncelikli yasaların koruma mevzuatının üzerinde olması vd.dir.

İdari, yetki sınırlarının dere havza ölçeğinde ele alınmaması havza büyüklüğüne bağlı yerel, idari sınırları aşmasından dolayı denetimi, uygulamaları bir ve/veya çok sayıda idari kurumun yetkisinde bırakmaktadır. Örneğin; havza ölçeğinde bir derenin membasından mansabına kadar olan uzunluğunu yerel idari yetki açısından araştırıldığında; I 38 (\%82) adet dere havzası tek belediye, 19 (\% II) adet dere havzası 2 belediye, 5 (\%3) adet dere 3 yerel belediye, 5 (\%3) adet dere 4 yerel yönetim sınırı içerisinden; I (\%I) adet dere 5 yerel belediye sınırından geçmektedir. Örneğin; Avrupa yakasında bulunan Ayvalı-Çırpıcı Deresi 5 farklı yerel yönetim sınırı içerisindedir. İ sınırını aşan I adet dere sistemi ise Ağva deresidir. Kaynak kolları Kocaeli İlinde mansap İstanbul İli içerisinde Karadeniz'dir (Şekil 2).

c) Teknik problemler; doğasına aykırı, amprik olmayan tasarım, mühendislik yöntemleri; hidrolojik ve hidrolik (dere; atıksu) verilerin ve bu verilerin değişiminin gözlemlenmesi, denetlenmesi vd. verilerin yetersizliği; güncellenmeyen drenaj teknolojileri; havza ölçeğinde yaklaşmayan münferit çözümler, kıyı ekosisteminin yok sayan ISLAH adı altında yok edici mekanik mühendislik yaklaşımlar, kaynak kontrolünün yapılmaması, planlama eksikliği, tüm yaklaşımlarda çevre etkisinin doğal yaşam odaklı hesaplanmaması vb. nedenler olarak sıralanmaktadır. 


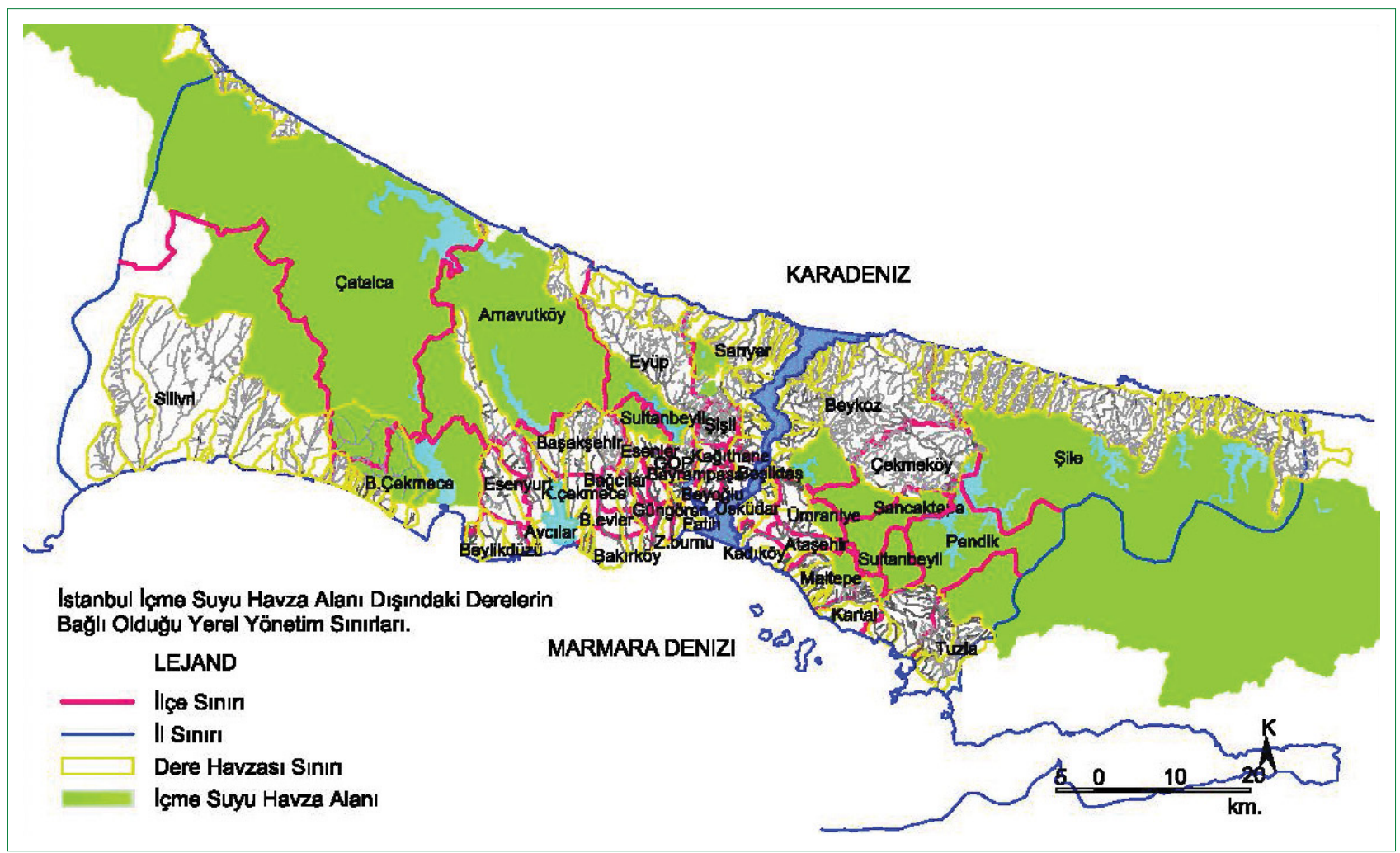

Şekil 2. İstanbul'da içme suyu havza alanı dışında kalan dere hatlarının geçtiği yerel yönetim bölgeleri.

Örneğin, derelerin fiziksel dönüşümünde en belirgin etkenlerden biri, dereleri korumak adına uygulanan tamamen yok edici etkiye sahip ıslah teknikleridir. Dere sistemlerine doğal yapısına aykırı uygulanan ıslah tekniğindeki mühendislik yaklaşımı, derelerin fiziki yapısının değişimini doğrudan etkileyen faktörlerden biridir (Şekil 3 b, c).

Dere sistemlerinin doğal yapısına aykırı beton veya taş malzeme ile açık ve/veya kapalı kesit sisteminde ıslah edilmesi, doğal yapısını, doğal drenaj havza özelliğini, barındırdığı habitatları ve doğal ekolojik koridorlarını kaybettirmekte; çevre yaşam kalitesini düşmesine neden olmaktadır.

d) Insan faktörü; araştırmalarda dere sistemlerinin koruma zonlarının yasa dışı yapılaşmaların ve atık su, moloz vb. kirleticilerin kaynağının en büyük nedeni insan faktörü ve dere sistemlerinin denetimsiz olduğu tespit edilmiştir. Dere sistemleri bölge yaşayanları tarafından kirlilik, tehlike vd. problemler olarak görülmektedir.

IBB, II Çevre Düzeni Plan Raporunda da, değişen ve kaybolan dere hatları üzerindeki hava, kara, kıyı ulaşım, sanayi, vd. ekonomik faaliyetlerin etkisi, çevre değerlerinde geri dönüşü zor olan hatta olmayan sürece taşıdığı belirtilmiştir (IBB, 2009).

Dere sistemlerinin fiziki durumunu ortaya koyacak, problemleri belirginleştiren araştırmanın yöntemi ve bulguları aşağıda sunulmaktadır.

\section{Araştırmanın Metodolojisi}

Makale, İstanbul'un içme suyu havza alanı dışında bırakılan, yaklaşık 2740 kilometrekare (yüzölçümün \%5I) alanda, Karadeniz, Boğaziçi, Marmara, Haliç ve göllere dökülen, açık havza konumunda olan dere sistemlerinin araştırılmasıdır. Çalışma, ana dere havza sınırlarının ve dere sistemlerinin belirlenmesini sağlayan harita çalışmalarını; her havzada bulunan akar dere hatlarının kıyı boy kesitinin fiziki yapısının ve üzerindeki arazi yapısının tespitini; elde edilen bulguların karşııılı analizini; bulguların kavramsal araştırmalar çerçevesinde sel ve taşkın riski açısından değerlendirilmesini kapsamaktadır.

Araştırmada, İstanbul'un dere ve vadilerini ortaya koyan ulusal ve uluslararası yasal mevzuat vd., yazılı ve görsel belgelerden (eski İstanbul haritaları, fotoğraflar vb.), dijital haritalardan (İstanbul İli I/I000 ölçek 5680 adet halihazır (2007 tarihli) paftalar, vb.), yerinde gözlemlerden yararlanılmıştır.

Kaybolmuş dere hatlarını saptayabilmek, fiziki durumunu tespit edebilmek, zaman içinde fiziki değişimi izleyebilmek ve ölçebilmek için elde edilebilen ilk sayısal haritalar olan 2007 onaylı I/I.000 ölçekli halihazır haritalar üzerinde çalışılmıştır.

Araştırmanın zeminini oluşturan harita, hazırlık süreci makro ölçek ve mikro ölçekte olmak üzere 2 aşamada aşağıdaki sırayla gerçekleştirilmiştir. 

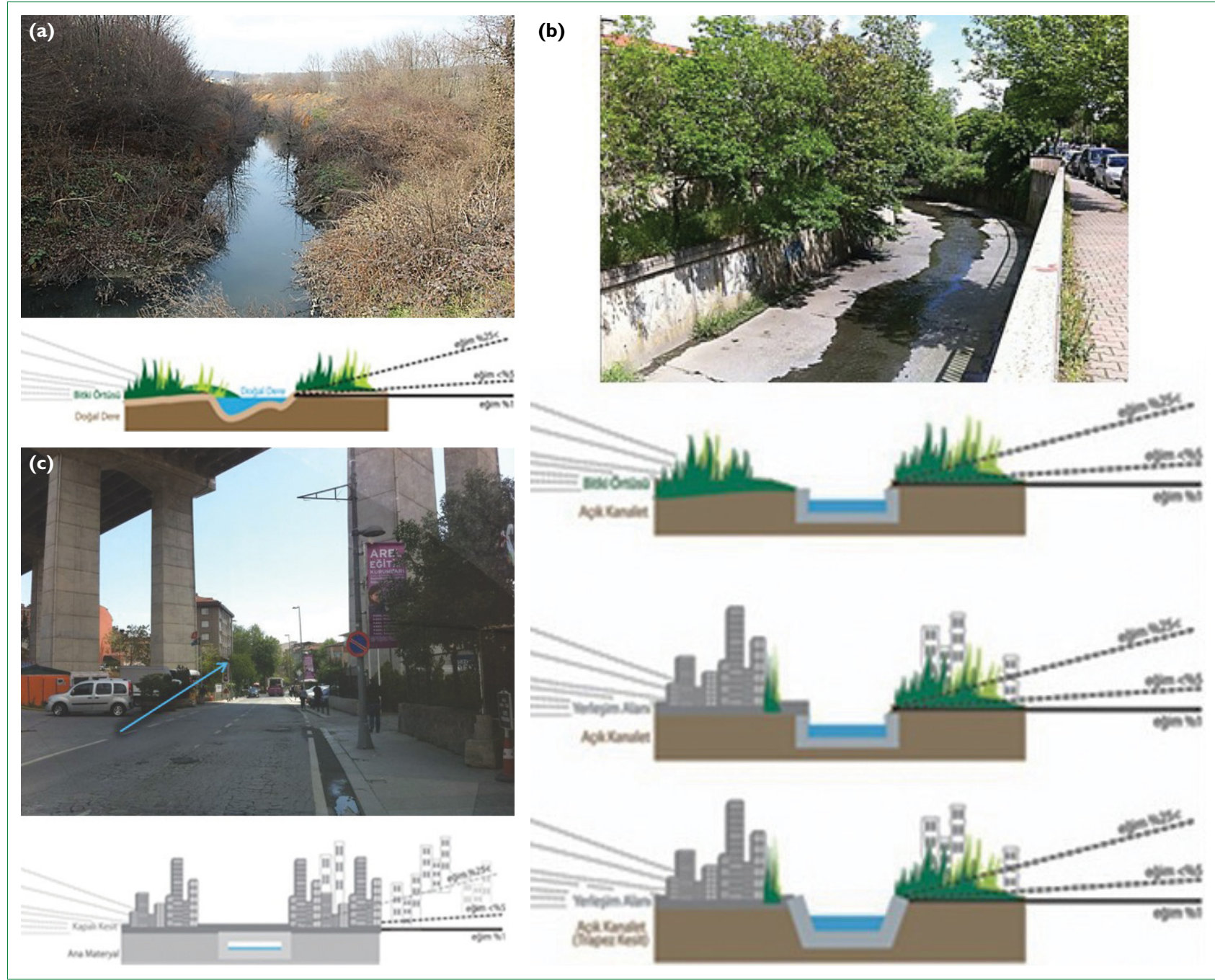

Şekil 3. Dere en kesitinin fiziki yapısı.

(a) Doğal dere sistemi.

(b) Açık kesit sistem. (c) Kapalı kesit sistem.

a) Makro ölçekte harita çalışmaları: Bu safhada, derelerin akar ana mecra ve kollarının tespiti için havza sınırlarının belirlenmesini, dere sistemlerinin tespitini, dere kıyılarının fiziksel yapısının ve koruma bandında arazi kullanım yapısının tespiti olmak üzere 3 aşamada gerçekleştirilmiş ve makro ölçekte İstanbul'un makroform gelişimi ile dere sistemlerinin ilişkisi analiz edilmiştir. Harita çalışmalarının aşamaları aşağıdaki gibidir.

i) Topografik eğriler yardımıyla derelerin ana dere havza sınırlarının belirlenmesidir.

ii) Ana dere havza sınırı içinde havza büyüklüğü, akar dere uzunluğu ve en kesit özelliğine göre derenin fiziki yapısının (doğal sistem; açık kesit sistem; kapalı kesit sistem) tespit edilmesidir. Analiz ve değerlendirme, havza ölçeğinde akar dere kollarında yapılmıştır; kuru dere sistemler değerlendirmeye alınmamıştır.

iii) Tespit edilen akar ana dere ve kollarının, bağı olduğu ilgili kurum yapılanma şartlarına göre dere işletme bantlarının (ko- ruma bandı ve/veya yapı yaklaşma sınırı) derenin her 2 yakasında belirlenmesidir.

b) Mikro ölçekte harita çalışmaları ise makro ölçekte tespit edilen ana dere havzasında, dere kıyılarının en kesitine göre fiziki yapısı ve arazi kullanım yapısının araştırılmasıdır. Derelerin her iki kıyısında tespit edilen fiziki yapısı ve arazi kullanım şekli, tablo ve şemalar yardımıyla benzer ve/veya farklılıklarıyla tanımlanması, analizi, elde edilen bulgular değerlendirilmesi; dere sistemlerini doğal yapısıyla sürdürülebilirliğinin sağlanması için önerileri yaklaşımlarını kapsamaktadır. Mikro ölçekte harita çalışmaları 3 aşamada hazırlanmıştır.

i) Derelerin fiziki yapısının tespiti; derelerin tespit edilen en kesit formlarını (doğal sistem, açık kesit sistem ve kapalı kesit sistem) harita çalışmalarında lejandla tanımlanması (Şekil 3ac); dere boy kesiti boyunca her iki yakasının mansap özelliklerine göre kategorileştirilerek sayısallaştırılmasıdır (Tablo I). ii) Derelerin arazi kullanım yapısının tespiti; dere sistemleri- 


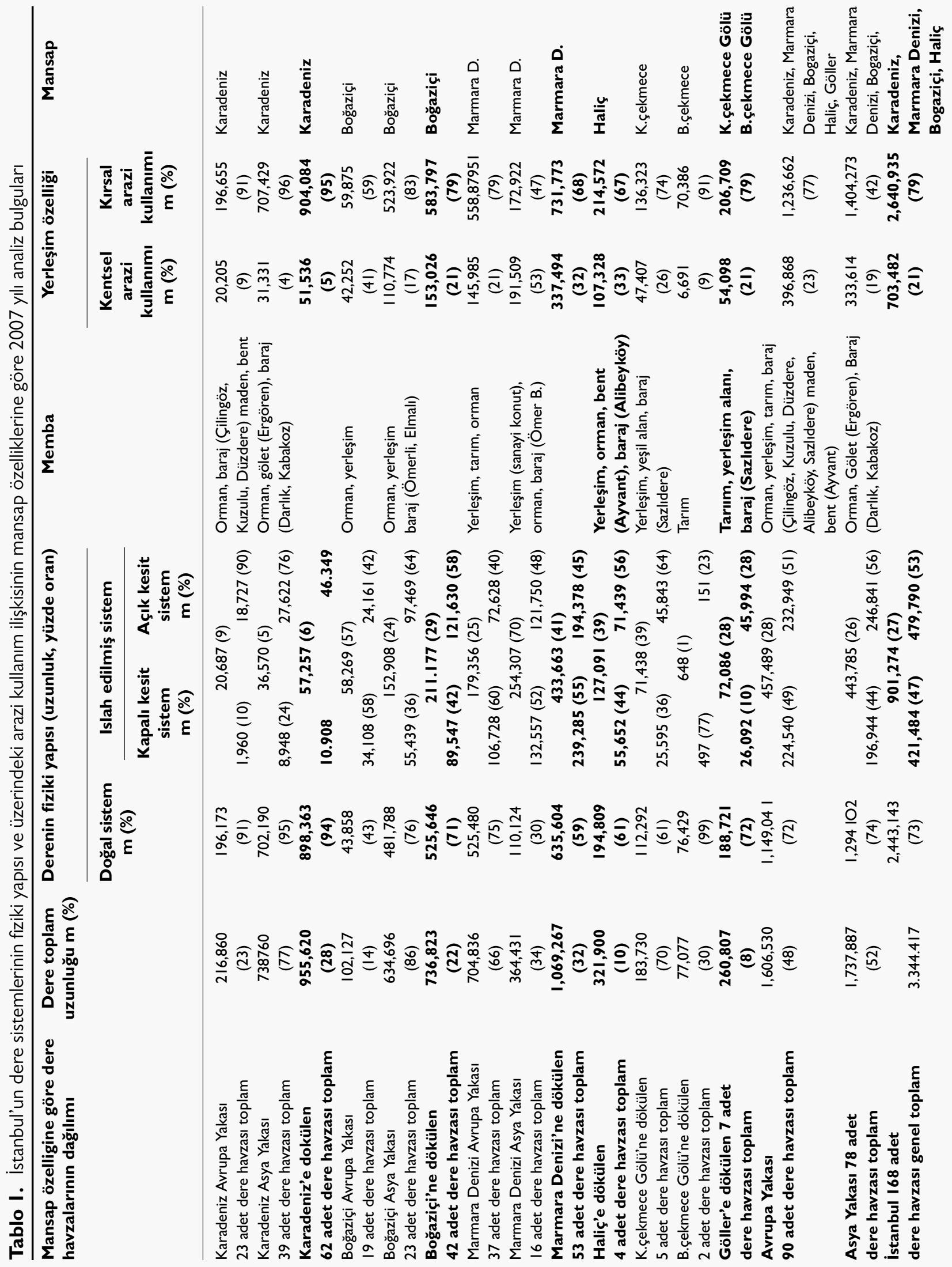


nin her iki yakasında ilgili kurum yönetmeliklerin tanımladığı dere işletme (koruma) bandında kalan, derelerin üzerinden geçtiği arazi kullanım yapısının tespitidir. Örneğin orman, ticaret, sanayi, konut, resmi kurum (eğitim, sağlık, vd. kamu kurumları), yeşil alan (mezarlık, park alanları), tarım, kumsal, yol vd. lejant ile tanımlanarak mansap özelliklerine göre kategorileştirilerek sayısallaştırılmasıdır (Tablo I). Araştırma, ilk aşamada derelerin geçtiği arazi yapısının gösterdiği farklılıklar ayrı ayrı tespit edilmiş olsa da sentez çalışmasında orman, tarım, yeşil alandan geçen dereler kırsal yerleşim alan; ticaret konut, sanayi vd. kentsel yerleşim alan olarak 2 ayrı grup altında kategorileştirilerek analiz edilerek değerlendirilmiştir.

iii) Derelerin fiziki değişimi ve arazi kullanım ilişkisinin analiz süreci

Elde edilen dere sistemlerinin fiziki değişimi ve arazi kullanım türünü gösteren 2 harita, dijital ortamda superpose edilerek, iki yapı arasındaki ilişkinin karşılaştırılmasıdır.

Yukarıda tanımlanan makro ve mikro ölçekte araştırma yöntemlerinde elde edilen bulgular ve analizi aşağıda sunulmaktadır.

\section{Araştırma Bulguları}

Araştırma bulguları aşağıda, makro ölçekte dere sistemlerinin İstanbul'un makroform gelişimi ile ilişkisinin analiz bulguları; mikro ölçekte derelerin fiziki değişimi ve üzerinde bulunduğu arazi kullanım bulguların analizi ve risk açısından değerlendirmesi olmak üzere 3 bölümde anlatılmaktadır.

\section{Makro Ölçekte Araştırma Bulguları}

İstanbul, Marmara Bölgesi'nde, Avrupa ve Asya kıtalarının birbirine bağlandığı noktada 5.400 km²'lik yüzölçümüyle, coğrafyayı şekillendiren dere ve vadileri ile bölge, ülke ve kıta ekosistem geçişlerinde önemli jeopolitik ve jeostratejik yerde konumlanmaktadır.

İstanbul'un halihazır haritaları(2007) üzerinde yapılan araştırmada, İçme Suyu Havza Alanı dışında kalan; Karadeniz, Marmara, Boğaziçi, Haliç ve Küçükçekmece ve Büyükçekmece Göllerine dökülen açık havza konumunda (Tablo I); 168 adet ana dere havzası ve bu havzalarda akar konumda olan $3.344 \mathrm{~km}$. uzunluğunda dere mecrası ve kollarının olduğu tespit edilmiştir. Bu dere sistemlerinin yaklaşık \%52'si, (I.737 km; 78 adet dere havzası) İstanbul ilinin Asya yakasında; \%48'i ( $1.606 \mathrm{~km}$; 90 adet dere havzası) Avrupa yakasında bulunmaktadır. İstanbul'un makroform gelişim süreci ile dere sistemleri arasındaki ilişki havza bazlı değerlendirdiğinde, yaklaşık \%80'i yerleşim alanında kaldığı kentsel baskı altında olduğu; \%20'si ise yerleşim alanlarının dışında kentsel baskıdan korunduğu tespit edilmiştir.
Kentin makroform gelişim sürecinde dere sistemleri araştırıldığında; İstanbul yerleşiminin tarihsel gelişim sürecinde kentin ve doğal sistemlerin üzerinde önemli rol oynayan Bizans Dönemi, Osmanlı Dönemi ve Cumhuriyet Dönemleridir.

İstanbul, Bizans Döneminde sur içinde 5.800 hektar yüzölçümüne sahipken, 1950 'li yıllarda yaklaşık 20 bin hektar alan; 2000 'li yıllarda ise 5.400 kilometrekareyi aşan büyüklüktedir (Şekil 4). İstanbul'un kentsel gelişimin içerisinde dere ve vadileri, Bizans döneminden 1950 yıllarına kadar doğal yapısını koruduğu, kentli ile doğa ilişkisinin yüksek olduğu çeşitli yazılı ve görsel kaynaklardan tespit edilmektedir (Yazır, 1984; Koçu, 1963; Kuban,2004. Url- 3,4..vd.).

Cumhuriyet dönemi ve sonrasında; özellikle 1950'den sonra artan nüfusa paralel olarak kara yolları, 1970'li yıllardan sonra Anadolu ve Avrupa yakasını birbirine bağlayan köprüler, kentin morfolojisi ve gelişim yönünü hızla değiştirmiştir. Bu değişim paralelinde dere ve vadilerini etkilemiş; derelerin kent ve kentliyle ilişkisini de dönüştürmeye başlamıştır.

İstanbul, 1950 yılından sonra, dere yataklarında başlayan sanayi üretimi, değişen ulaşım modelleri ve çağırdığı göçün etkisinde hızla şekillenirken, dereler çeşitli müdahalelerle kent baskısında kalmaya başlamıştır. Bu süreçler, derelerin doğal yapısını etkilemiş, fiziki yapısını zaman içerisinde değiştirerek kaybetmesine neden olmuştur. Örneğin; Vatan Caddesinin olduğu yerden geçerek Yenikapı'dan denize dökülen tarihi Bayrampaşa (tarihte Lekop veya Lykos adıyla bilinen) deresi Ortaköy, Ihlamur, Bebek dereleri, gibi dereler 1950'li yıllardaki imar hareketleriyle kapalı sistem kanallar içerisine alınmıştır. Günümüzde kanal içinde akan derelerin üstü yayaaraç yolu olarak kullanılmaktadır. Geçmişte doğal yapısıyla kent ve kentliyle bağı güçlü olan dere ve vadileri, zamanla çevresindeki yapı yoğunluğunun ezici baskısıyla fiziki yapısı değişerek kentle organik bağı koparılmıştır (IBB, 20I0).

Eski fotoğraflar ve yazılı kaynaklara göre, derelerin doğal yapısına yapılan çeşitli müdahaleler, derelerin kentle ilişkisini de belirlediğini göstermektedir (Yazır, 1984; Koçu, 1963; Kuban, 2004; Dağdelen 2006; Pervititich 2000; Yetişkin 2010, Url3,4..vd.). Örneğin, 19.yy ortalarından 20.yy sonlarına kadar rekreasyon, mesire, su alma, su yolu ulaşımı, balıkçlık, bahçecilik gibi amaçlarla kullanılan; kentlinin bir araya geldiği, toplumsal gelişmenin sağlandığı çok yönlü kamusal alanlar olmuşlardır. Günümüzde ise bu ilişki kaybolmuş (Kurbağalı dere, Göksu dereleri gibi) ya da kaybolmak üzeredir (Kağıthane, Göksu, Küçüksu, Riva vd).

Geçmişte, derelerin denize açıldığı mansapları kent plajları ve küçük balıkçı teknelerinin sığındığı koylardı. (Turşucu deresiSuadiye plajııı; İdealtepe deresi Süreyya plajı, Çamaşırcı deresi 


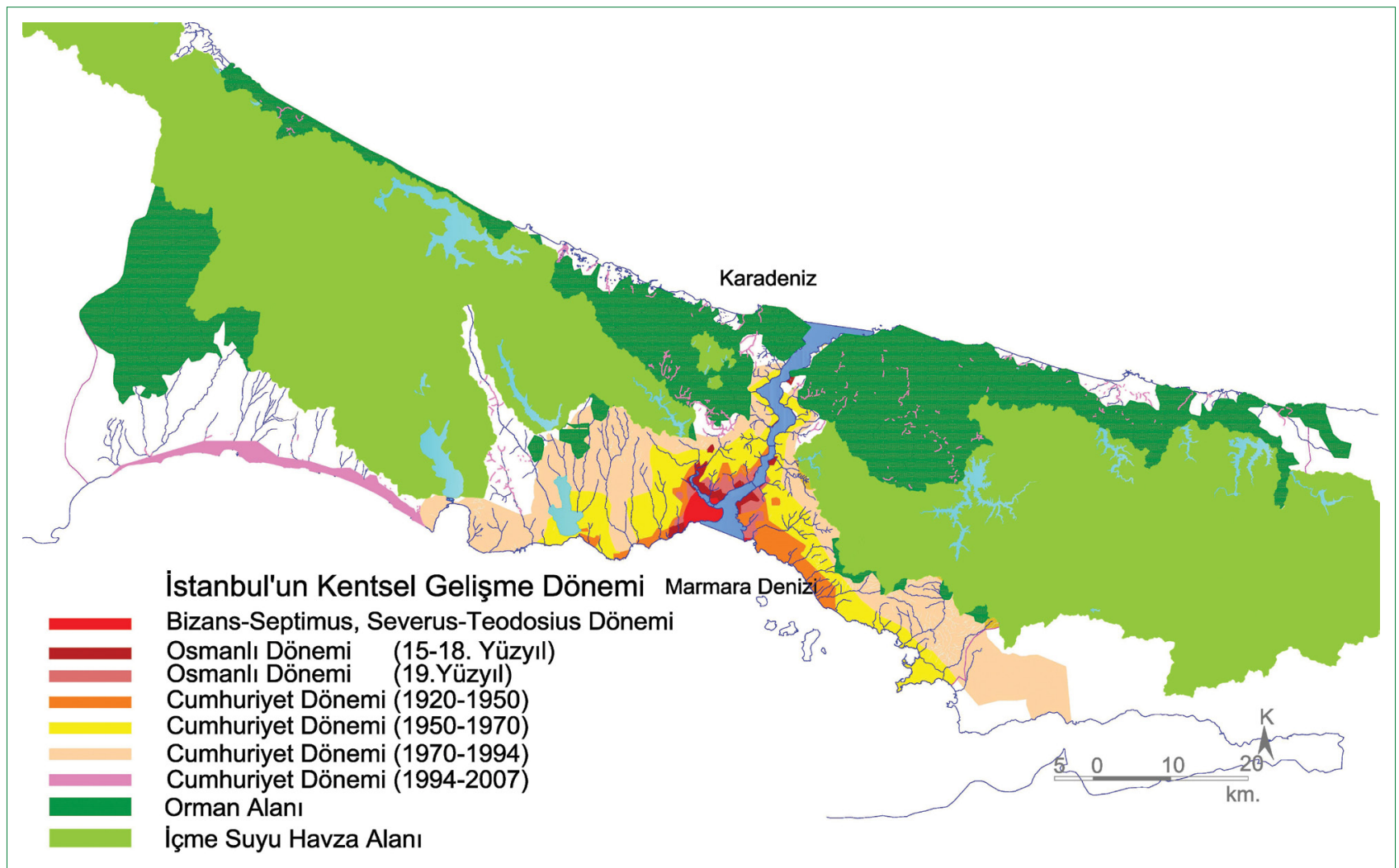

Şekil 4. İstanbul'un makroform gelişimi içerisinde dere sistemleri (Makroform sınırları ve Orman sınırları il Çevre Düzeni Plan (2009) raporundan yararlanılarak; 1994-2007 dönemi ise 2007 halihazır haritalardan yeniden düzenlenmiştir).

Bostancı Plajı, Florya deresi Florya plajı, Kurbağalı dere Kalamış plajı, Ayamama, Tavukçu dereleri Ataköy plajı gibi.). Bugün bu mansap bölgeleri yerleşim alanlarında kalmıs, kıyıların doldurulmasıyla koy ve kumsal özelliğini kaybetmiştir.

Kent içerisinde kalan derelerin çoğu doğal kıyı ekosistemini kaybetmiş; taş ve betonarme malzeme ile açık ya da kapalı kanal kesit olarak denize, göle ve Haliç'e bağlanmaktadır. Membaları geçmişte açık alan, yeşil alan, orman alanı, tarım alanı, su havza alanı vb. bölgelerde yer alırken; günümüzde çoğu yerleşim dokusu içerisinde kalmıştır. Kentin gelişme dönemlerinde; dereler kentleşme ile fiziki değişime uğrarken kentli ile ilişkilerinin de kaybolduğu gözlenmiştir.

İstanbul içme suyu havza alanı dışında kalan derelerin 2007 yllı halihazır haritalar üzerinde yapılan tespitlerde toplam 168 adet dere havzasının \%20'si (33 adet) yerleşim alanı dışındadır. İstanbul dere havzalarının yaklaşık \%80'i yerleşim alanında kaIıp, kentsel baskı altındadır.

Kent makro formunun şekillenmesine paralel olarak değişen dere sistemlerinin doğal yapının bozulmasında en önemli etkenlerden bazıları ulaşım, sanayide-endüstri, yasa dışı yapılaşma gibi yerleşim kararları olmuştur. Her dere sistemi vadi, tabanı (dere yatakları) ve tepeleri ile kendine özgü morfoloji ve doğal özelliklere sahipken doğal özelliklerinin azaldığı, birbirine benzer hale geldiği, ve hatta kaybolduğu, yapısal yoğunluğun ön plana çıktığı İstanbul Boğaziçi kent silüeti oluşmuştur. Beton, su ve bitki örtüsünün yerini alarak su ile toprak arasında kurulmuş olan dengeyi bozmuştur/bozmaktadır.

Günümüzde kent makroformunun belirleyicisi yerleşim ve ulaşım kararları, yasa dışı yapılara getirilen aflar gibi doğa merkezli olmayan hatalı yasa, idari, teknik gibi uygulama yaklaşımları devam ederse, İstanbul'un korunmakta olan dere sistemleri de dönüşerek çevresel riske dahil olacaktır.

Makro ölçekte kentin makroform gelişimi içerisinde tespit edilen dere havzaları ve dere sistemlerinin 2007 yılı verilerine göre fiziki yapısının durumu ve arazi kullanımla ilişkisinin araştırma sonuçları aşağıda mikro ölçekte açıklanmıştır.

\section{Mikro Ölçekte Araştırma Bulguları}

İstanbul yüzölçümünün yaklaşı \%5I'ini kaplayan içme suyu havza alanı dışında kalan 2740 km² $^{2}$ alanda yapılan makro ölçek araştırmada, 168 dere havzası, yaklaşık 3.344 kilometre uzunluğunda akar dere konumunda olan dere sistemi tespit edilmiştir. Tablo I'de tanımlanan dere sistemlerinin fiziki yapısı ve üzerindeki arazi kullanım yapısının bulguları ve derelerin 


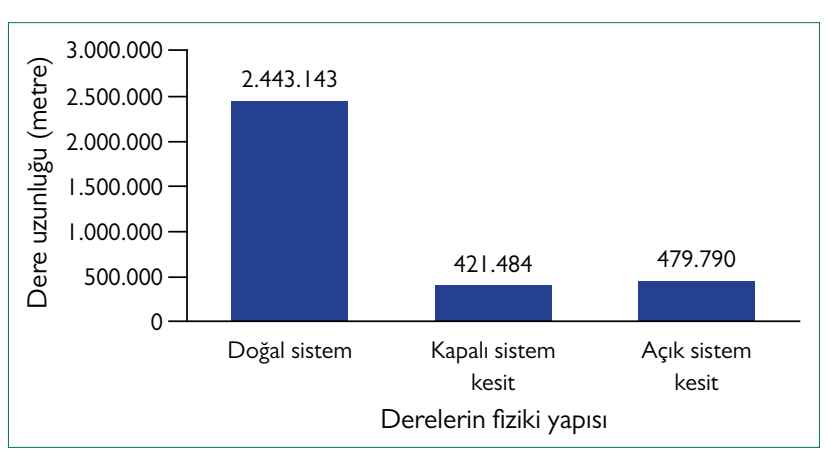

Şekil 5. İstanbul içme suyu havza alanı dışındaki derelerin fiziki yapısı.

fiziki değişimi ile arazi kullanım arasındaki ilişkinin analizi havza ölçeğinde değerlendirmesi aşağıda anlatılmaktadır.

\section{a) Dere sistemlerinin fiziki yapısına ait bulgular}

Dere kıyılarının en kesiti araştırıldığında, dere sistemleri doğal yapısının dışında mühendislik uygulamaları nedeniyle açık kesit ve kapalı kesit sitem olmak üzere 3 temel formda bulunmaktadır.

Dere sistemleri boy kesitine göre fiziksel yapısı araştırıldığında; yaklaşık $3.344 \mathrm{~km}$ uzunluğunda olan dere sistemlerinin \%73'ü doğal yapısını koruduğu; \%27'si ise açık veya kapalı kesit olarak ıslah edilerek fiziki değişime uğradığı ve doğal kıyı ekosistemini kaybettiği tespit edilmiştir. Islah edilen derelerin \%44'ü açık kesit sistem, \%53’ü ise kapalı kesit sistemdir (Şekil 5, Şekil 6, Tablo I).

Bulgular, dere havza ölçeğinde (drenaj havzası) değerlendirildiğinde, 168 adet dere havzasının \%36'sı (60 dere havzası), dere sistemlerini membadan mansaba kadar doğal yapısını korumakta; \%64'ü (108 dere havzası) ise çeşitli dışsal müdahalelerle fiziksel yapısını tamamen ve/veya kısmen kaybetmiş ve/ veya kaybetmektedir (Tablo I).

Dere sitemlerinin fiziksel yapısının araştırmaları, dere en kesitinde 3 ana tipoloji (doğal yapı sistemle birlikte açık, kapalı kesit sistem) olduğunu ve bu 3 tipolojinin derelerin boy kesitinde çeşitli kombinasyonlarla bir araya gelerek yeni formlara dönüştüğünü göstermektedir. Bu formlar gruplandığında toplam 7 tipolojiye rastlanmıştır. Bunlar; açık kesit dere sistemleri, kapalı kesit dere sistemleri, doğal dere sistemler, doğal+kapalı+açık kesit dere sistemleri, kapalı+açık; doğal+kapalı; doğal+açık kesit dere sistemlerinin kombinasyonları olmak üzere 7 farkIı tiptedir (Şekil 7). Açık kesit sistem dere tipolojisine, dere havza ölçeğinde tek tip olarak rastlanmamıştır; doğal ve kapalı kesit sistemlerle kombinasyon halindedir.

Bir çeşit derenin restorasyonu olarak uygulanmakta olan fakat dere sistemlerinin doğal yapısına aykırı olan bu mevcut ıslah uygulama teknikleri; dere sistemlerinin değişiminde hatta kaybolmasında önemli etkenlerden biri olduğu tespit edilmiştir.

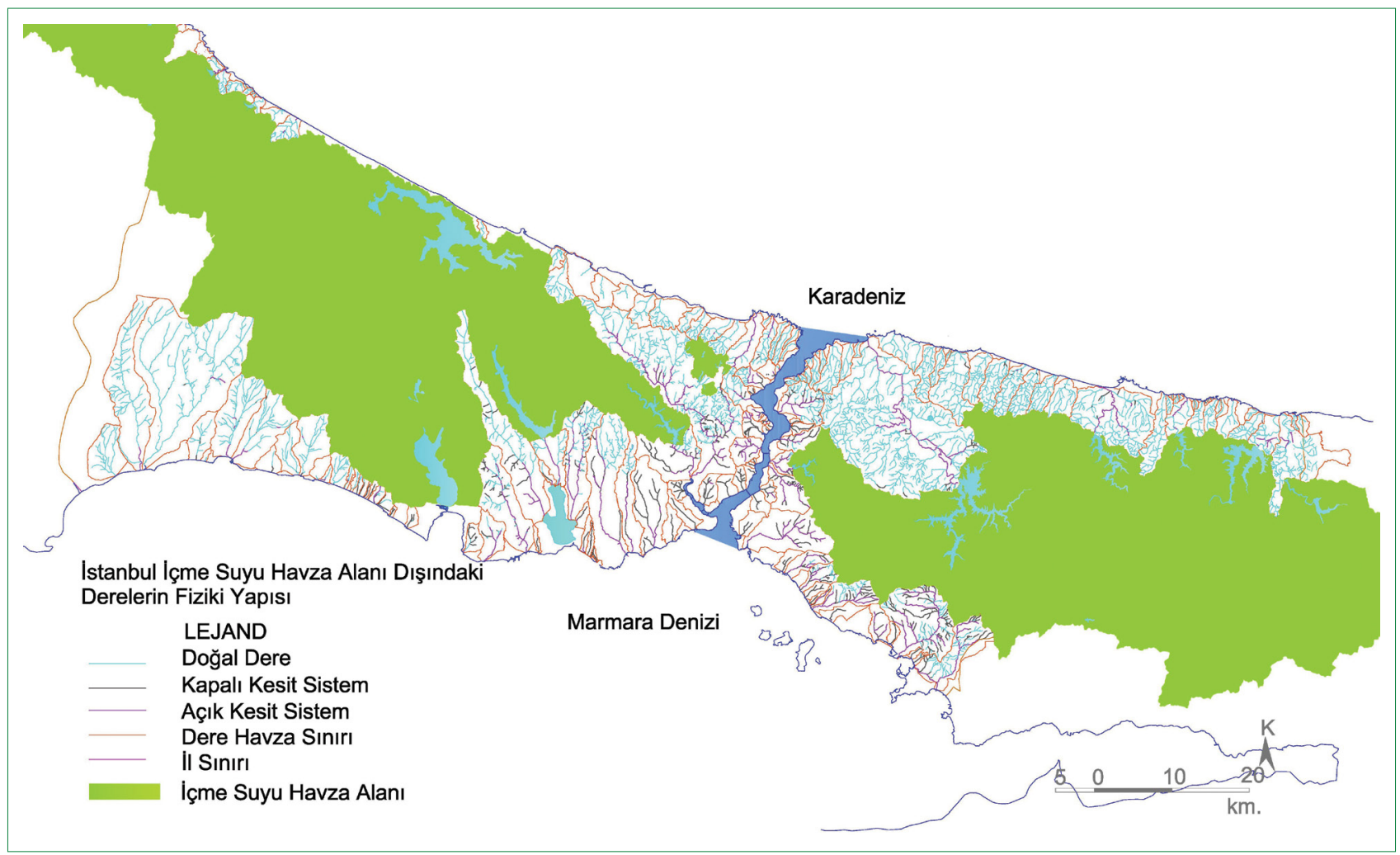

Şekil 6. İstanbul'un içme suyu havza alanı dışında kalan derelerin boy kesitine göre fiziki yapısı. 


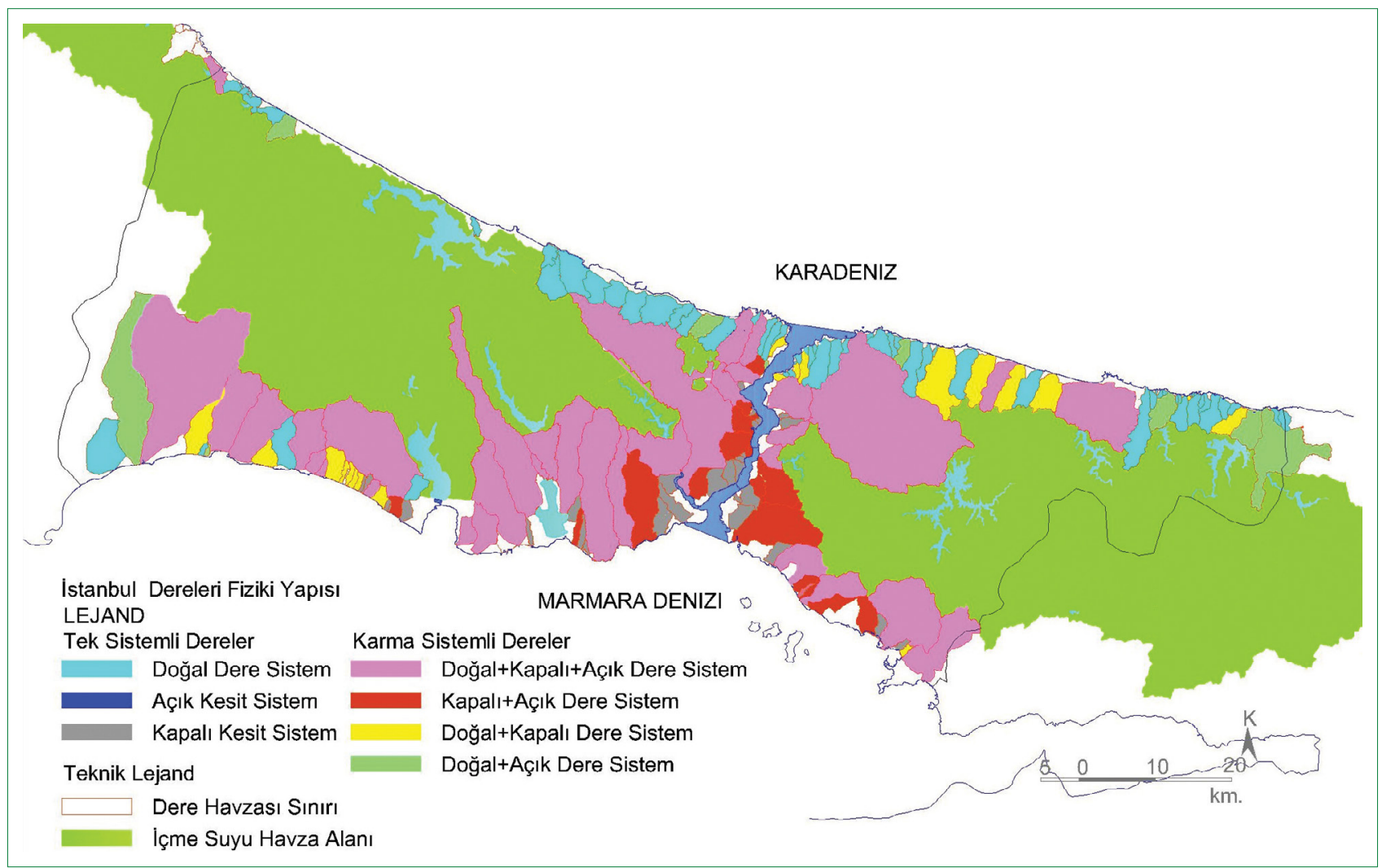

Şekil 7. İstanbul'un içme suyu havza alanı dışında kalan derelerin fiziki yapısının havza ölçeğinde oluşturduğu tipolojiler.

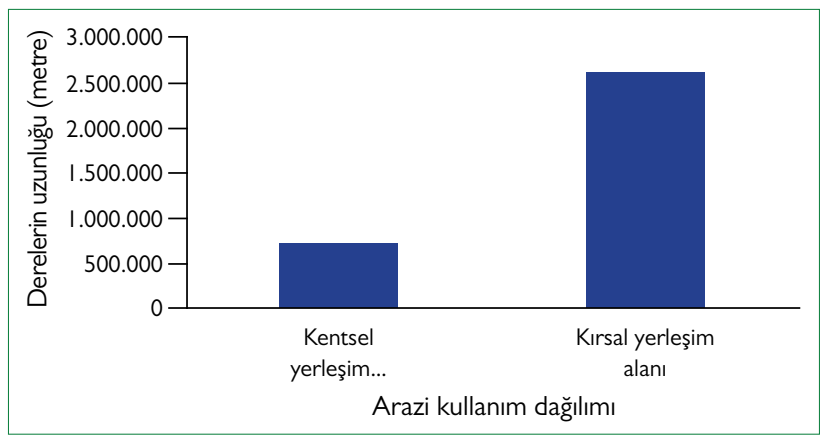

Şekil 8. İstanbul'un içme suyu havza alanı dışında kalan derelerin arazi kullanım ilişkisi.

\section{b) Arazi kullanım bulguları}

Makro ölçekte, kent makroformunun belirleyici olduğu arazi kararlarına göre, dere sistemlerinin üzerindeki arazi kullanım kararı havza ölçeğinde (drenaj havzası) değerlendirildiğinde; 168 adet dere havzasının \%20'si (33 adet) orman, tarım vb. yerleşim alanı dışında; \%80'i (I 35 adet) kentsel yerleşim alanı içerisinde kalmaktadır (Şekil 8, Tablo I).

Dere sistemleri üzerindeki arazi yapısıyla ilişkisi boy kesitine göre araştırıldı̆̆ında; toplam boy kesitin \%2l’i (703km.) kentsel yerleşim alanında; \%79'u (2.64l km.) kırsal alanda bulunmaktadır (Şekil 8, Şekil 9, Tablo I).
Dere sistemlerinin her iki yakasında 10 metre (Boğaziçi'ne dökülen) ve 35 metre (Karadeniz, Marmara, Haliç ve Göller'e dökülen) koruma bandında (tampon veya işletme bandı) yer alan arazi kullanım yapısı; konut, ticaret, sanayi (maden vd.), orman, tarım, yeşil alan, yol, eğitim-belediye hizmet alanı, kumsal yerleşim dokuları vb. tespit edilmiş ve bu donatılar birbirleriyle kombinasyonlar içerisindedir.

Dere sistemlerinin üzerindeki arazi kullanım yapısı, Tablo I'de de sunulduğu gibi, mansap özelliklerine göre kategorileştirilerek aşağıda özetlenmiştir.

- Karadeniz'e dökülen derelerin \%95'i kırsal alandan (\%83 orman, \% 2 tarım); \%5'i kentsel (konut, ticaret vd.) alandan geçmektedir (Şekil I0).

- Boğaziçi'ne dökülen derelerin \%79'u kırsal (Orman) \%2l’i kentsel yerleşim alanlarından geçmektedir. Boğaziçi'ne dökülen derelerin orman alanından geçen ve etkili olan deresi Riva Dere havzasıdır (Şekil 10).

- Marmara Denizi'ne dökülen derelerin \%68'i kırsal (\%23'ü orman, \%3।'i tarım \%।4'ü yeşil) alandan; \%32'si kentsel alandan geçmektedir (Şekil I0).

- Haliç'e dökülen derelerin \%69'u kırsal (orman); \%3l'i kentsel alandan (\% I0 Sanayi, \%8 Konut, \%2 eğitim-belediye hizmet alanı ve \% I I diğer kentsel ve kırsal karma arazi kullanımları) geçmektedir. Haliç'e dökülen derelerden en 


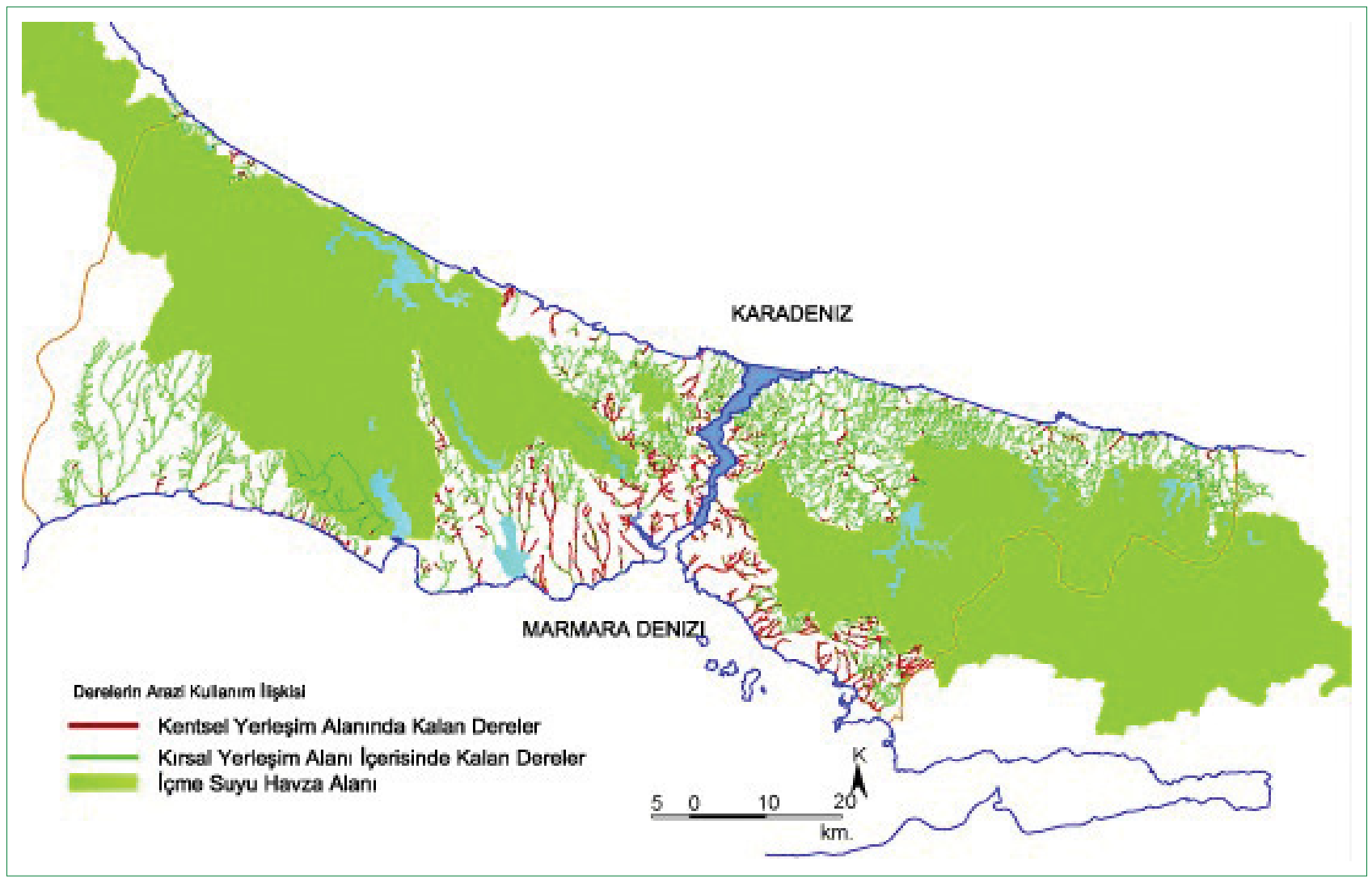

Şekil 9. İstanbul'un içme suyu havza alanı dışında kalan dere sistemlerinin üzerinde olduğu arazi kullanım yapısı.

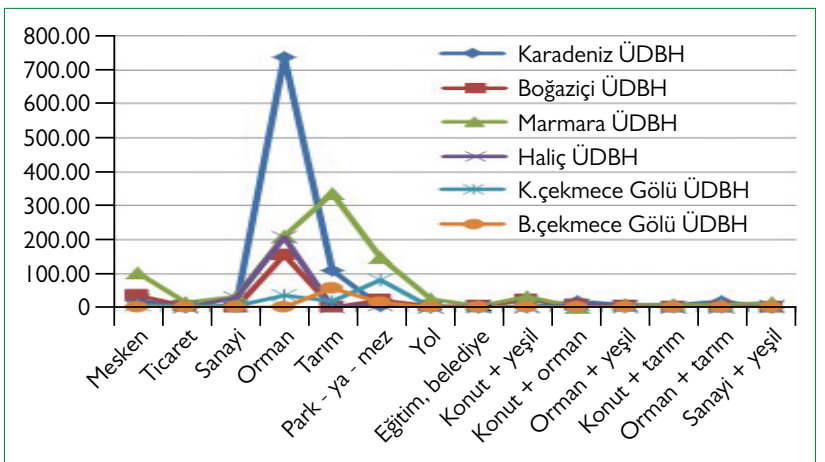

Şekil I0. İstanbul'da dere sistemlerinin üzerinde olduğu arazi kullanım ilişkisinin analizinin mansap özelliklerine göre kategorileştirilerek dağıım grafiği.

etkili olan Kağıthane Dere havzasıdır (Şekil I0).

- Küçükçekmece Gölü'ne dökülen derelerin \%74'ü kırsal alandan (\%45 yeşil alan; \%20 orman, \%9 tarım); kentsel alandan \%26'sı (\%6 konut, \%3 sanayi, \%3 ticaret, \%। yol, $\% 2$ eğitim, belediye hizmet alanı; \%।I diğerleridir) geçmektedir (Şekil I0).

- Büyükçekmece Gölüne dökülen derelerin \%79'u kırsal (\%7l'i tarım, \%20'si yeşil alan), \%29'u kentsel alandan (\%II'i konut, konut+tarım, \%/8'i sanayitorman, sanayi+yeşil vd.) geçmektedir (Şekil I0).

Bu tespitler özetlenirse, Karadeniz ve Boğaziçi'nin kuzeyine dökülen dereler orman alanında koruma içerisinde kalmakta; yapılan araştırma tarihi itibariyle (2007) yerleşimin baskısından korunmaktadır. Boğaziçi'nin güneyine doğru ve Marmara denizine dökülen dereler konut, sanayi, ticaret gibi karma ve yoğun arazi kullanımının üzerinde yer almaktadır. Marmara denizinin Avrupa yakası güney batısına dökülen dereler tarım, konut ve yer yer sanayi yerleşim alanları, kıyıları yazlık konut dokusuyla ilişkidedir.

Dere koruma bandında yer alan arazi kullanım yapısı eğitim gibi kamu binaları, sanayi, konut, yol, aktif rekreasyon alanları vb. yapısal donatılar hem kıyı ekosistemini yok eden uygulamalar hem de taşkın alanı içerisinde zamanın işgalci yapıları olup çevresel riskleri oluşturacak/yaşayacak alanlardır.

\section{c) Derelerin fiziki değişimi ile arazi kullanım arasındaki ilişkinin analizi}

Derelerin fiziki yapısına ile üzerindeki arazi kullanıma dair bulguların analiz sonucuna göre, dere sistemleri yerleşim merkezlerine yaklaştıkça yapısal müdahalelerle fiziki yapısını değiştirdiği; ve bu değişimin arazi kullanım yapısı ile doğru ilişkili olduğunu göstermektedir (Tablo 2, Şekil II, Tablo I). En belirgin kanıtı ise fiziki yapsının doğasına aykııı form almasıdır.

Dere boyunca dere fiziki yapısının sık değişmesi ve çeşitlenmesi; arazi kullanımının çeşitliliğini, yapılaşma yoğunluğunu, 
Tablo 2. İstanbul'un içme suyu havza alanı dışında kalan dere sistemlerinin fiziki değişimi ile arazi kullanım ilişkisinin analizi

\begin{tabular}{|c|c|c|c|c|}
\hline \multirow[t]{2}{*}{ Mansap özelligine göre dere havzaları (I68 DH) } & \multicolumn{2}{|c|}{ Arazi kullanım (metre) } & \multicolumn{2}{|c|}{ Dere fiziki yapısı (metre) } \\
\hline & Kentsel yerleşim & Kırsal yerleşim & Dogal dere & Islah edilmiş sistem \\
\hline Karadeniz’e dökülen DH & 51.536 & 904.084 & 898.363 & 57.257 \\
\hline Boğaziçi'ne dökülen $\mathrm{DH}$ & 153.026 & 583.797 & 525.646 & 211.177 \\
\hline Marmara Denizi'ne dökülen DH & 337.494 & 731.773 & 635.604 & 433.663 \\
\hline Haliç'e dökülen DH & 107.328 & 214.572 & 194.809 & |27.09| \\
\hline K.çekmece Gölü'ne dökülen DH & 47.407 & 136.323 & II 2.292 & 71.438 \\
\hline B.çekmece Gölü’ne dökülen DH & 6.691 & 70.386 & 76.429 & 648 \\
\hline Toplam & 703.482 & 2.640 .935 & 2.443 .143 & 901.274 \\
\hline
\end{tabular}

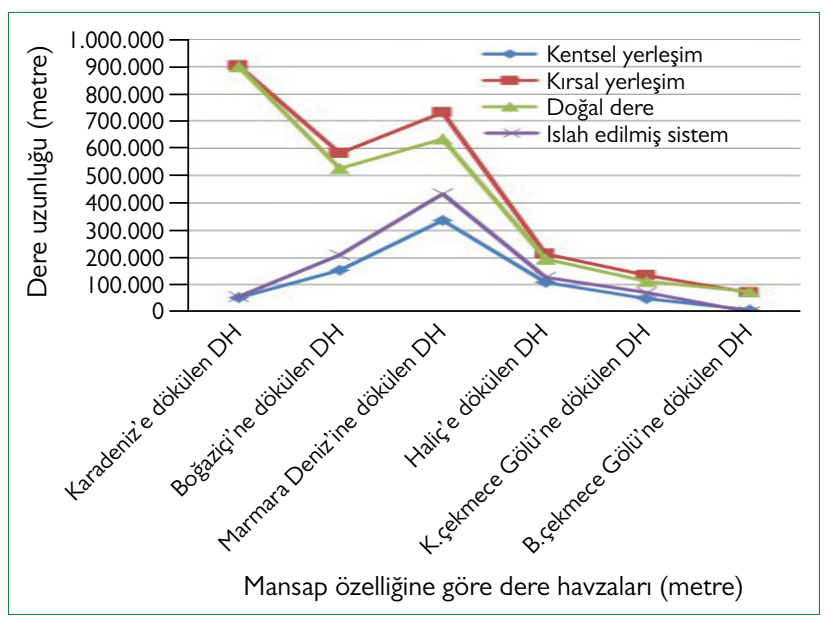

Şekil I I. İstanbul'un içme suyu havza alanı dışında kalan derelerin fiziki değişimi ile arazi kullanım ilişkisi analizi.

yapılaşmanın dereye olan mesafesinin yakınlığı ile ilişkili olduğunu göstermektedir.

Dere sistemlerinin fiziki yapısının arazi kullanım ilişkisi ile oluşturduğu tipolojiler, kent ve kentlinin doğal yaşam ile ilişkisini de belirlemektedir

\section{Araştırma Bulgularının Drenaj (sel, vd.) Riski Açısından Değerlendirilmesi}

İstanbul'un 168 dere havzasında 3.344 km uzunluğunda akar dere sistemine sahip olduğu, ciddi su potansiyeli bulunduğunu göstermektedir. Kuru dereleri ile birlikte yüzey sularını toplayan/dağıtan dere (=su) potansiyelinin çok daha fazla olduğunu göstermektedir. Bu dere sistemleri açık havza konumunda olması etki sahasını yerelden uluslararası ölçeğe taşımaktadır.

Uluslararası kavramsal araştırmalara göre, değişen havza morfolojisi, havza yüzeylerinde artan yapılaşmalar, fiziki değişime uğrayan dere sistemleri vd. faktörler nedeniyle doğal drenaj dengesinin bozulması; bölgede taşkın, kuraklık gibi çevresel riskleri oluşturacaktır. Araştırılan dere sistemlerinde fiziki yapısına bağlı çevresel risk yaratacak alanlar aşağıdaki haritada gösterilmektedir (Şekil 12).

Risk açısından dere sistemleri havza ölçeğinde (drenaj havzası) değerlendirildiğinde, 168 dere havzasının \%36'sında (60 dere havzası) dere sistemi membadan mansaba kadar doğal yapısını koruduğu tespit edilmiştir. Kavramsal araştırmalar, bu havzalarda doğal drenaj sisteminin dengede olduğunu; bozulmayan doğal kıyı ekosistemi ile su kalitesinin korunduğu, habitat yaşamların, ekolojik koridorların, vd. doğal yaşam sistemlerin sürdürülebililiğinin sağlandığı, çevresel risklerin azaldığı; iklim değişiminin etkisini yönetilmesinin kolaylaştığı; kente/kentliye sunduğu sağlıklı çevre yaşam kalitesi ile sürdürülebilir ekoloji, ekonomiyi katkı sağladığı/sağlayacağını göstermektedir.

Fiziki değişime uğrayan dere sistemleri havza ölçeğinde risk açısından değerlendirildiğinde; araştırılan dere havzalarının \%64'ünde yer alan dere sistemleri kısmi/tamamen fiziki değişime uğramıştır. Fiziki değişime uğrayan dere sistemlerin bulunduğu bu havzalar ( 108 dere havzası), doğal yapısını koruyan dere havzalarından daha etkili drenaj problemi vd.çevresel riskleri taşımaktadır.

Dere boy kesitindeki fiziki yapısındaki değişimi risk açısından değerlendirildiğinde, fiziki değişime uğrayan yaklaşı 703 km. (\%2I) uzunluğundaki dere sistemlerinin yakın çevresinden havza ölçeğine yayılan taşkın, sel, vb. riskli alanları oluşturacaktır. Dere sistemlerinin boy kesitindeki bu fiziksel değişimlerin İstanbul geneline dağınık ve yaygın olması; çevresel problemlerin yarattı̆̆ı/yaratacağı sorunların büyük ve etkili olacağına göstermektedir.

Bulgular, nüfus projeksiyonuna göre güncellediğinde (2007 yılı İstanbul nüfusu 12.5 Milyon kişi, 2017 yılında 15 Milyon kişidir), sadece nüfus yoğunluğunun \%20 artmasıyla risk oranının \%76'ya çıktığını; İstanbul'un yüzölçümünün \%5l'inin sel, taşkın ve kuraklık gibi risklere terk edildiğini; bu durumun çevre sağlığı ve yaşam kalitesini düşüreceğini göstermektedir. 


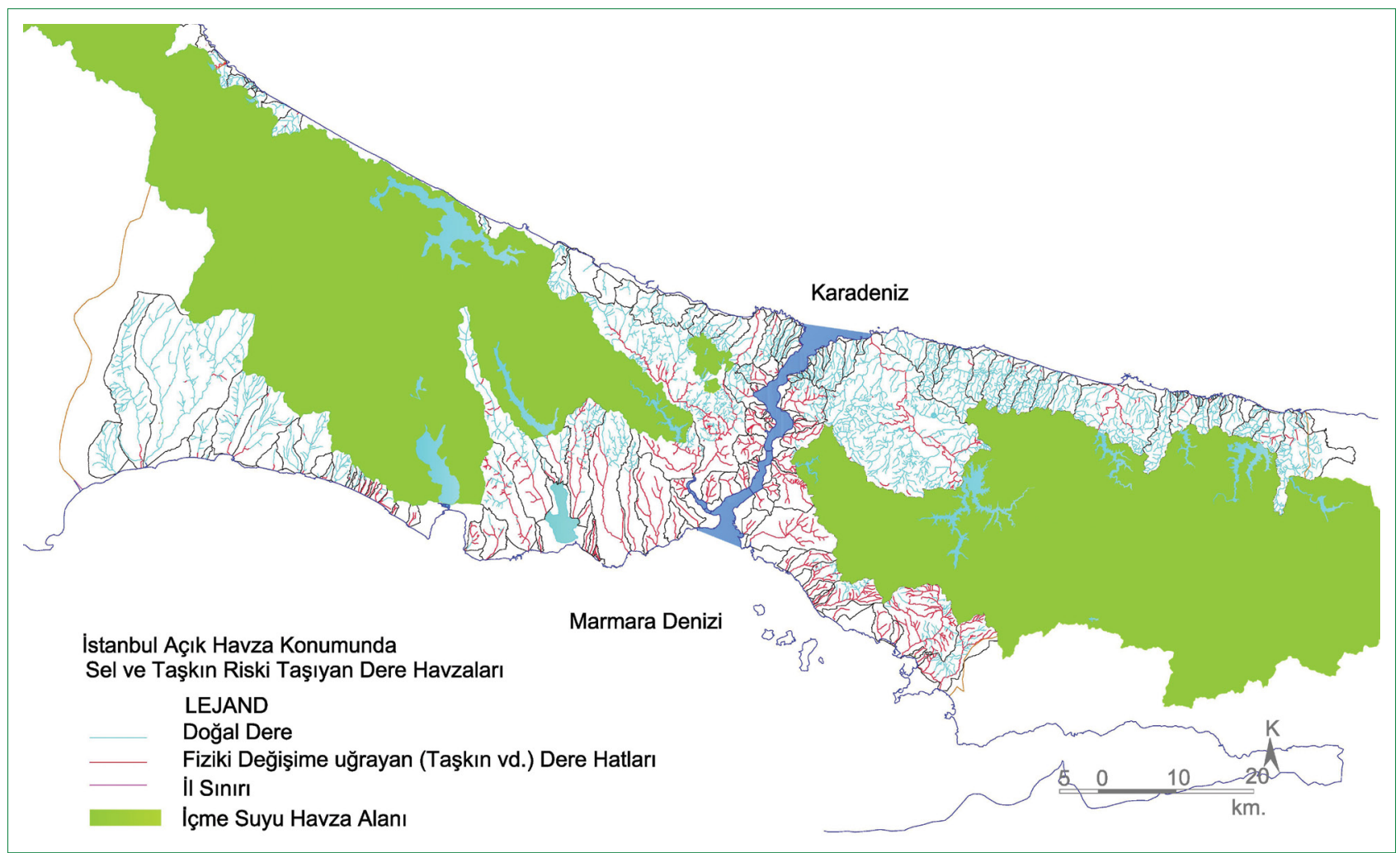

Şekil I2. Fiziki değişime uğrayarak çevresinde risk oluşturacak dere hatları.

Fiziksel yapısını değiştiren ve/veya kaybolan (gerçekte kaybolmayan) dere sistemleri yapılaşmayla birlikte havzasının drenaj yoğunluğunu değiştirerek sel ve taşkın risklerle birlikte başka yaşamsal riskleri de getirecektir. Başlıcaları; susuzluk/kuraklık, suyun kalitesinin bozulması, biyoçeşitlilik, habitatların, vb. kaybolması, depremde risk oluşturması, vd.dir.

Açık havza konumunda olan dere sistemlerinde yaşanan bu problemler, sadece yerel ölçekte etkili olmayıp; İstanbul İli'nin konumunun jeopolitik ve jeostratejik önemi ile bölgesel ve küresel ölçeğe de yansıyarak geniş alanlarda etkili olacaktır.

Araştırma bulguları, dünyanın küresel alarma geçtiği İklim değişimi ile artacak sel/kuraklık ve diğer çevresel problemlere İstanbul kentinin hazır olmadığını ve riskleri yönetemeyeceğini göstermektedir.

$\mathrm{Bu}$ nedenle, su ekosisteminde dere sistemlerinde ve dere havza yaklaşımlarında yasal, teknik, idari, vb. açıdan yaşanan mevcut problemlere ivedilikle çözüm üretilmesi gerekmektedir. Eğer mevcut durum değiştirilmezse, İstanbul için özellikle son dönemde kentleşme yönünün kuzeye doğru yayılmasıyla korunmakta olan doğal derelerin üzerinde de sel, taşkın, kuraklık vb. benzeri etkiler yaşanacak; mevcut risk alanlarına yeni bölgeler katılacak, iklim değişimine uyum sağlanamayacak, yağışların ve kuraklığın kent ve kentli üzerinde maddi/manevi zararları daha fazla ve hasarı geri dönülmez boyutta olacaktır.
Dere sistemleri üzerindeki analizler, problemlerin çeşitliliği, sahaya yaygınlığı nedeniyle, çözümün devlet kontrololünde makro ölçekte havza bazlı, disiplinlerarası ilişkiyi kuracak, doğa yaklaşımlı yeni bir planlama yaklaşımına ihtiyaç olduğunu göstermektedir.

\section{Sonuç ve Problemlere Çözüm Yaklaşımı}

Son yıllarda artan sel, taşkın, kuraklık gibi yaşamı tehdit eden/ edecek faktörlerden ders çıkartan uluslar, coğrafyalarında yerel, ulus ve uluslararası önlemler alarak iklim değişimini yönetmeyi ve faydaya çevirerek dirençli kentleri oluşturmaya çalışmaktadırlar.

Makro ölçekte problemlerin en önemli çözüm aktörü olan planlama, ilgili disiplinlerle birlikte, korunmakta olan su ekosistemlerin sürdürülebilirliğini sağlanmalıdır. Bozulan dere sistemlerin iyileştirilmesi için, su ekosistemlerinin mevcut durumunu yerel ve ulusal gündeme ivedilikle taşınmalı; uluslararası, ulusal, yerel ölçekte sistemlerin birbirleriyle ilişkisini kuracak planlama yaklaşımı ile çözümler üretilmelidir.

Yasal problemler değerlendirildiğinde: Ulusal yasa ve yönetmeliklerde derelere gönderme yapan su ekosistemini parçalayan; koruma aleyhine olan yasa ve yönetmelikler, plan kararları iptal edilmelidir. Bunun yerine dere sistemlerini havza ölçeğinde ele alan bütüncül su hukukuna ihtiyaç vardır. Ulusal 
su hukuku, dere/nehir/göl gibi su ekosistemini küresel zeminde uluslararası ortaklaştırılacak bir üst su hukukunu olmalı; ulusal su hukukunun üstünde farklı bir yasa kabul görmemelidir. Değişimle ilgili izleme, yetki ve sorumluluk yerelden uluslararası ölçekte yönetişim yaklaşımıyla ele alınmalıdır. Ülkenin dere sistemlerini ilgilendiren uluslararası ölçekte imzaladığı su kaynakları, biyoçeşitlilik, vb. doğal yaşam kaynaklarını korumaya yönelik sözleşmeleri uygulamaya girmelidir.

Planlama ile ilgili problemler değerlendirildiğinde; su ekosisteminin parçası olan dere sistemlerini bütüncül ele almak için planlama şemsiyesinde disiplinler arası koordinasyon kurulmalı; plan ölçeklerinin dere havza ölçeği ve diğer ölçeklerle ilişkisi sağlanmalıdır. Planlamada kentleşme öncesi/süresince bölgenin havza ölçeğinde doğal ve kültürel peyzaj envanterleri çıkartılmaIı, peyzaj programları ÇED raporları hazırlanmalı, izlenmelidir.

Yönetmelik değişikliği ile dere sistemlerini parçalayan, dere vasfından çıkartılan kuru dereler, gibi yağış sularını toplayan ve boşaltan tüm doğal sistemler dere vasfına alınarak korunma altına alınmalıdır. Her dere sisteminin kendi havzasının özelliğine bağlı taşkın kotu mesafesi tespit edilerek su kıyısı ekosisteminin korunması ile ekolojik koridorların bütünlüğü sağlanmalıdır Tespitlere göre, koruma banlarının içinde dere sistemlerinin doğal yapısına aykırı kaçak ve işgalli alanlar boşaltılmalı; bu zonlar imar affı/imar barışı kapsamı dışında kalmalıdır. Yeniden işgallerin ve herhangi bir yapısal tasarımların, aktif rekreasyonların önünü kesmek için gerekli müeyyide ve denetimi sağlayacak yasal kararlara ihtiyaç vardır. Dere sistemleri üzerinde insan davranışları kontrol altında tutulmalıdır. İmar barışı adıyla getirilen aflarla imara açılan dere sistemlerinin taşkın koruma zonlarındaki yapılaşmalar, kamulaştırılarak geri alınmalıdır.

Her dere havzasının doğal morfolojisinin doğal, kültürel vb. envanterleri üzerinde havza ölçeğinde arazi kararları alınmalı ve diğer dere havza ölçekler ile ilişkileri analiz edilerek üretilmeli; uygulamalar gerçekleşmeli ve değişimler izlenmeli, değerlendirilmelidir.

Planlamada, koruma zonları gibi doğal yaşam alanları ve bu alanların kullanım şekilleri planlarda tanımlanmalıdır. Riparian zon, taşkın zonu, sucul yaşam alanı, hava koridorları; ekolojik koridorlar, habitat yaşam alanları, biyolojik zincir gibi doğal yaşam koridorlarını yerleşim alanlarından ayrı, kendi doğasında sürdürülebilirliğini sağlaması için plan ölçekleriyle dere havza sistemleri ilişkisi kurulmalıdır.

Araştırmada tespit edilen idari sorunlar değerlendirildiğinde, su ekosisteminde mülkiyet, idari görev ve yetkilerde, yasal, yönetsel vb. işleyişteki çeşitliliğin yarattığı sorunlar, dere/nehir sistemlerine bütüncül havza ölçeği ile çözülebileceğini göstermektedir. Bu kapsamda, çalışma sahası ve izleme alan sınırı, dere havza sınırı (su ayırım çizgisi-hattıbala) olmalıdır. Bu yaklaşım doğal bilimler dahil birçok disiplini aynı zeminde bir araya getirecektir. Ortak çözümlerin üretimini, birlikte çalışmayı, izlemeyi, riskleri kontrol altında tutmayı kolaylaştıracak, doğa ile planlamayı, tasarımı, mühendisliği ortak alanda birleştirecektir. Birden fazla yerel yönetim ya da idari sınırı aşan dere sistemlerini tek yerel ve idari birimde toplayacak olan dere havza ölçeği ve dere havza sistematiğinin plan ölçeği ilişkisi arazi kararlarında değerlendirilmelidir. Bu nedenle dere havza ölçeğinde tüm idari birimlerde, yerel sınırlarda ortak çalışma modeli oluşturulmalıdır.. Dere havza ölçeklerinin plan ölçekleriyle ilişkisi sağlandığında dere/nehir sistemlerinin entegre havza planlaması, entegre havza yönetimi ve izleme, değerlendirilmesi işlemlerini kolaylaştıracağı düşünülmektedir.

Teknik açıdan problemler değerlendirildiğinde, havzanın hidrolojik dengesini kontrol altında tutmak, havza ölçeğinde suyun akış yönünü dikkate alan yerleşim kararları alınması ve/ veya planlanması ile mümkündür. Uygulama öncesi havza ölçeğinde su toplama/dağıtma, akış yönlerini ve arazi kullanımın kontur-gabari subasman kotlarını gösterecek yüzeyleme planı; hidroloji izleme ünitesinin kurulduğu drenaj sistem planlaması hazırlanmalıdır.

Dere sistemlerinin teknik, kurumsal ve yasal çerçevede birleştiren, havza ölçeğinde çok disiplinli master planları hazırlanmalıdır. Master planlama teknik özellikleri; kurumsal işleyişi; yasal yaptırımları kapsamalıdır. Teknik yaklaşımda, sel erozyon, taşkın, sedimantasyon ve su kirliliğine yol açan etkenler tanımlanmalıdır. Drenaj sistemi proje yöntemleri güncellenerek yeni drenaj teknolojileri yaygınlaştırılmalı ve gelişimi desteklenmelidir.

Kırsal ve kentsel alanlarda bozulan/zarar gören dere/nehir/göl/ deniz kıyı ekosistemleri tespit edilerek; “Doğal” mühendislik çözüm teknikleri ile kendi doğal yapısına yeniden kuracak dere/nehir restorasyonu gerçekleştirilmelidir. Seli yönetmek ve faydaya çevirmek için, kapanan derelerin, nehir ekosistemlerin restorasyonu ile doğal yapısı yeniden kazanılarak ekolojik koridorlar güçlendirilmeli; nehir/dere sistemlerinin iklim değişikliğine uyumuna yardımcı olması sağlanmalıdır.

Havzaların hidrolojik özelliklerini kaynaktan mansaba kadar takip edecek, üst ölçekte (bölge) yağmursuyu yönetimi drenaj ofisi kurulmalı; bu birim ilişkili belediye vd. kurumlar arasında işbirliği desteklenmeli; kentsel planlama kararlarını ve hazırlanacak master planlama kararlarını bir arada yürütmelidir. Yasal uygulama araçları için stratejiler oluşturulmalıdır. Yüksek risk taşıyan hidrolojik alanların işgali engellenmeli; rölyef önlemleri alınmalı; kentleşmede sel, erozyon, su kirliliği çevre etki değerlendirmeleri yapılmalı; kıyı ekosistemi, hidrolojik eşikler koruma zonlarıyla birlikte drenaj ofisleri tarafından izlenmelidir. 
Dirençli sağlıklı kentler oluşturmak için doğa-insan, çevretoplum ilişkileri, davranışları doğal yaşam odaklı planlamanın tüm bileşenlerinde ve ölçeklerinde yeniden gözden geçirilmelidir. Planlamayı mekanik algıdan (salt fiziki plan, tasarım anlayışından) çıkaracak yeni bir planlama yaklaşımı ile doğal yaşam sistemlerine uyumlu ortak çevre hukuku ve ahlakı geliştirilmelidir. Bunun için, doğa merkezli (yaşam odaklı) bütüncül planlamada eksik olan yasal, idari, teknik vd. problemler çözülerek sağlıklı çevre, yüksek yaşam kaliteli, dirençli kentler inşaa edilmelidir.

$\mathrm{Bu}$ çalışma, İstanbul derelerinin fiziki durumunun tespiti ve arazi kararları ile ilişkisini somut bulgularla açıklayan, doğal sistemler üzerinden dirençli, yaşam kalitesi yüksek kentleri oluşturmak için ileriye dönük ölçek niteliğinde araştırma makalesidir.

Araştırma makalesi, doğal sistemleri koruyarak sürdürülebilirliğini sağlamak ve riskleri yönetmek için, devlet denetiminde su ekosistemini bütün olarak ele alacak yasal, planlama, yönetim, yönetişim yaklaşımıyla örgütlenme, network sistemi, teknik uygulama, İzleme ve geri besleme, gibi süreçleri kapsayacak bütünleşik dere havza planlaması, master planlama, entegre havza yönetimi, havza ölçeğinde drenaj planlaması, doğal dere restorasyonu vb. yaklaşımları kapsayan yeni bir yapılanmanın gerekli olduğunu göstermektedir.

\section{KAYNAKLAR}

Allan, J. D. (2012). Landscapes and Riverscapes: The influence of land use on Stream Ecosystems. Annual review of ecology, evolution and systematics. Vol. 35(2004), 257-284, Michigan Üniversitesi.

Allan, J. D., Erickson, D. L., and Fay, J. (1997). The Influence of Catchment Land Use on Stream Integrity Across Multiple Spatial Scales. Freshwater Biology, vol 37, 149-162.

Anderson, D. G. (1970). Effects of urban development on floods in Northern Virginia. Water in The Urban Environment: Geological Survey WaterSupply Papper. Washington, USA.

Booth, D. B. (1991). Urbanization and the natural drainage system-impact, solutions and prognoses. The Northwest Journal. Vol.7, No 1, (s.93-117), Wahington Univrsity, USA.

Booth, D. B., Karr, J. R., Schauman, S., Christopher, P. K., vd. (2004). Reviving urban streams: Land use, Hydrology, Biology and human behavior. Journal of American Water Resources Association. (s.1351- 1364), USA.

Bosch, J. M. and Hewlett, J. D. (1982). A review of catchment experiments to the determine the effect of vegetation changes on water yield and evapotranspiration. Journal of Hydrology. Vol.55, 3-23, Elsevier Scientific Publishing Company, Amsterdam, Netherlands.

Bölen, F. v.d. (2009). İstanbul'da yapılaşma yoğunluğu yaşanabilir alan ilişkisi. İTÜ Dergisi: Mimarlık, planlama ve tasarım. Cilt 8, Sayı:1, (s:127-137), Mart 2009, İstanbul.

Brown, K. B. (2000). Urban stream restoration practices: An initial assessment. The center for watershed protection. Elliot City, MD.

Burgess, J., Harrison, C. M., Limb, M. (1998). People, parks and the urban green: a study of popular meanings and value for open spaces in the city. Urban Studies. Vol:26, 5, 6, (s.455-473).

Campbell, C. J. (1971). Pressure bomb measurements indicate water availability in a Southwestwen Riparian Community. Rocky Maountain forest and regime experiment station. The Pennsylvania State Universty Libraries.

Carlston, C. W. (1963). Drainage density and streamflow, physiographic and hydraulic of rivers. Geological survey professional paper. Washington, USA.

Corbett, E. S., and Lynch, J. A. (1985). Management of streamside zones on municipal watersheds. Ripirian ecosystems and The management: Reconciling conflicting uses, 1 .North American Riparian Kenferansı. (s.187190). Tucson, Arizona.

Correl, M. R., Lillydal, J. H. ve Singell, L. D. (1978). The effects of greenbelts on residental property values. Some Findings on the political economy of Open Space. Vol.54, (s.207-217).

Cushing, C. E., Cummins, K. W. and Minshall, G. W. Vd. (2006). River and stream ecosystems of the world. University of California Press.

Dağdelen, İ. (2006). Alman Mavileri 1913-1914 I. Dünya Savaşı Öncesi İstanbul Haritaları Cilt 1, 2, 3. TC. İBB Kütüphane ve Müzeler Müdürlüğü, ISBN 975-6582-78-2, 975-6582-79-0.

Dale, V. H., Brown, S., Haeuber, R. A., Hobbs, N.T., vd. (2000). Ecological principles and gidelines for managing the use land. Ecological Society of America(ESA) Report. Vol. 10 (3), 639-670.

Dunne, T., and Leopold, L. B. (1978).Water in environmental planning. San Francisco: W. H.| Freeman.

Dülger Türkoğlu, H., Bölen, F., Baran, P. K., Marans, R. W. (2008). İstanbul'da yaşam kalitesinin ölçülmesi. İTÜ Dergisi/a.Cilt 7 Sayı 2, İstanbul

Erman, D. C., Erman, N. A., Costick, L., and Beckwitt, S. (1996). Management and landuse buffers. Riparian areas and wetlands: Appendix 3, Kaliforniya Üniversitesi. http://www.sierraforestlegacy.org/Resources/ Conservation/FireForestEcology/ThreatenedHabitats/MontaneMeadows/Montane-Kattelmenn96.pdf.

Ernst, and Young (2003). Transfer pricing surveys, Global Survey: Practices, percetions and trends in 22 countries, plus tax authority approaches in 44 countries, EYGM ltd. Erişim adresi, www.ey.com.

Fausch, K. D., Torgesen, C. E., Baxter, C.V., and Li, H. W. (2002). Landscapes 
to riverscapes; briding the gap between research and conservation of stream fishes. Bioscience. 52, (s.483-489).

Fisher, S. G., and Likens, G. E. (1973). Energy flow in Bear Brook, New Hampshire: an integrative approach to stream ecosystem matabolism. Ecol. Monogr., 43, (s.421-439).

Gao, X. ve Asami, Y. (2005). Economic value of urban landscapes. Institute of Geografical Sciences and Natural Resources Reserch, Chinese, center for spatial information Science University of Tokyo, Japan http://www. csis.u-tokyo.ac.jp/dp/67.pdf.

Gatewood, J. S., Robinson, T. W., Colby, B. R., Hem, J. D., vd. (1950). Use of water by bottom-land vegetation in lower Safford Valley Arizona. Geological Survey Water-Supply Paper. U.S. Dept. Of Interior, 1103, (s.96), Vol 364.

Gordon M. F., John C. G., Daniel A. G. (1966). Water and Waste water Engineering. John Wiley and Sons Inc., New York.

Groffman, P. M., Bain, D. J., Band, L. E., Belt, K. T. vd. (2003). Down by the riverside: urban riparian ecology. The ecological Society of America, (s.315-321).

Hardesty, P., Kuhns, C. (1998). The Buffer Handbook: A guide to creating vegetated buffers for lakefront properties. Environmental protection agency, Boston Regional Office, Maine Department of Environmental Protection.

Hermoso,V., Pantus, F., Olley, J., Linke, S, Mugodo, j., Lea, P. (2011). Systematic planning for river rehabilitation: Integrating multiple ecological and economic objectives in complex decision-making scenarios Freshwater Biology. Vol. 58, 1-12.

Hollis, G. E. (1975). The effects of urbanization on floods of different recurrence intervals. Water Resources Research. Vol. 11, 431-435.

Horton, R. E. (1945). Erosional development of streams and their drainage basins; hydrophysical approach to quantitative morphology. Bulletin of the geological society of America(2011), Vol. 56, 275-370.

Hynes, H. B. N. (1970). The ecology of running waters. Toronto Üniversitesi yayin1, Toronto.

Iturbe, I. R., and Escobar (1982). The dependence of drainage density on climate and geomorphology. Vol 27 (2), 129-137. Hydrological Secience Journal.

İstanbul Büyükşehir Belediyesi. (2007). 1/100.000 Ölçekli İstanbul Hali Hazır Haritaları-2007 onaylı, Eişim tarihi: Kasım 11 2013. İBB, Harita Müdürlüğü, İstanbul. (CD-ROM).

İstanbul Büyükșehir Belediyesi. (2009). 1/100.000 Ölçekli İstanbul İl Çevre Düzeni Planı Raporu. Plan uygulama araçları, İBB, İmar ve Şehircilik Daire Başkanlığı Şehircilik Daire Başkanlığı, Şehir Planlama Müdürlüğü, İstanbul.

İstanbul Büyükşehir Belediyesi. (2009). İstanbul'un Asya, Avrupa Yakası Dereleri Raporu. İBB, Alt Yapı Mühendislik. İstanbul.

İstanbul Büyükşehir Belediyesi. (2010). Park Bahçeler Müdürlüğü. Erişim tarihi Mart 5, 2014, erişim adresi; http://www.ibb.gov.tr/tr-TR/BilgiHizmetleri/Istatistikler/Documents/bldhizmetleri/2010/parkvebahceler_mud_2004-\%202010.pdf.

İstanbul Büyükşsehir Belediyesi. (2011). İstanbul Metropolitan Alanı Kentsel Ulaşım Ana Plan Raporu. İBB, Ulaşım Daire Başkalığı Ulaşım Daire Başkanlığı. Şehir Planlama Müdürlüğü, İstanbul.

İstanbul Büyükșehir Belediyesi. (2013). Dere Islah Çalışmaları Notları Ek. Erişim tarihi, Aralık 2, 2013, erişim adresi: www.ibb.gov.tr/tr-TR/Documents/basinbulteni/../dereislahi_notlar_ek.doc.

İstanbul Büyükşehir Belediyesi. (2013). 1/25.000 ölçekli İstanbul'un dereleri, akarsu havza dışı derleri. İstanbul Su ve Kanalizasyon İdaresi (İSKİ). İstanbul, Erişim tarihi: Nisan 24, 2013. (CD-ROM).

İstanbul Büyükşehir Belediyesi. (2013). Dere Proses: Akarsu dere, akarsu havza içi, akarsu havza dışı dereler. İBB Alt Yapı Birimi. (CD-ROM). Erişim: Nisan 24, 2013.

İstanbul Büyükşehir Belediyesi. (2013). Avrupa-Asya yakaları havza Itrf, 12.03. 2007, 02.08.2006. İstanbul Su ve Kanalizasyon İdaresi (İSKİ). (CD-ROM).
İstanbul Büyükşehir Belediyesi. (2013). İçme Suyu Havzaları Yönetmeliği, 2 sayll karar, yayın tarihi 24 Ocak 2013.

Jhan, L. R., and Trefethen, J. B. (1972). Placing channel modificiations in perspective. In Watersheds in transition, proceedings of a symposium sponsored by the Water Resources Association and Colarado State University. (s.15-21), Fort Collins, Colorada: Colorada State Universty.

Jhonson, R. R., Carothers, S. W. (1982). Riparian habitats and recreation: Interralationship and impact in Southwest and Rochy Mountain Region. Senior research scientist, National Park Service, School of renewable natural resources and depertment of Ecology and Evolutionary Biology, Arizona Üniversitesi. http://www.fs.fed.us/rm/boise/AWAE/labs/ awae_flagstaff/Hot_Topics/ripthreatbib/johnson_carothers_riphabrec. pdf.

Jhonson, R. R., and Lowe C. H. (1985). On the development of ripirian ecology. http://www.fs.fed.us/rm/pubs_rm/rm_gtr120/rm_ gtr120_112_116.pdf.

Kahya, E. Erkek, C., Ağıralioğlu, N. (2006). Su Kaynakları Mühendisliği “Su Kaynaklarının Geliştirilmesi, Ders Notları. İnşaat Mühendisliği, İTÜ Beta Yayınevi, İstanbul.

Kauark, Leitte, L. A., Nascimento, N. O, Baptista, M. B. (1999). Stormwater masterplanning in developing tropical countries, impact of urban growth on surface water and graoundwater quality (Proceeding of IUGG). 99 Symposium HSS, Birmingham, IAHS. Yayın no: 259.

King, D., vd. (2012). Community-based agroforestry initiatives in Nicaragua and Costa Rica. Forest Wildlife Management. Minnesota Universitesi.

Kobold, M., and Seselj, K. (2005). Precipitation forecasts and their uncertainty as input into hydrological models. Hydrology and Earth System Sciences. No. 9 (4), 322-332.

Koçu, R, E. (1963). Boğaziçínde İskele, Kayık ve Sandalları. İstanbul Ansiklopedisi. 6.Cilt, Koçu yayınları, İstanbul Ansiklopedisi ve Neşriyat Kollektif Şirketi, İstanbul.

Kriken, J. L., Enquist, R., Rapaport, R. (2010). City Building-Nine Planning Principles for The Twenty-First Century. Princeton Architectural Press, New York.

Kuban, D. (2004). İstanbul Bir Kent Tarihidir. Tarih Vakfı Yurt Yayınları, İstanbul. ISBN:97533331304.

Lindsey, G. I., Man, J., Payton., Discon K. (2003). Amenity and recreation values of urban greenways. The Association of European Schools of Planning Congress. Leuven, Belgium.

Luttik, J. (2000). The value of trees, water and open space as reflected by house price in the Netherlands. Landscape and Urban Planning 48, 161-167.

May, C. W., Horner, R. R., Karr, J. R., Mar, B. W., Welch, E. B. (2014). The Cumulative Effects of Urbanization on Small Streams in the Puget. Sound Lowland Ecoregion.

http://www.researchgate.net/publication/240437080_Effects_of_urbanization_on_small_streams_in_the_Puget_Sound_Lowland_Ecoregion.

Mayer, G. E., Franti, T. G. and Mortensen D. A. (1997). Seek and destroymachine vision identifies weeds for spot spraying. Resource Magazine, Engineering and Technology for a Sustainable World. Vol.4(12),13-14, http://water.usgs.gov/wrri/AnnualReports/1998/NE98.pdf.

Mayer, P. M., Reynolds S. K., Canfield, T. J. (2005). Ripirian buffer width, vegetative cover and nitrogen removal effectiveness: A Review of current science and regulations. National Risk Management Research Laboratory office of research and development US. Environmental Protection Agency, EPA. Cincinnati, Ohio.

Melton, M. A. (1957). An analysis of the realtions among elements of climate, surface properties and geomorphology. Departman of Geology, Columbia University.

Minshall, G.W., Cummins, K. W., Petersen, R. C., Cushing, C. E., Bruns, D. A., Sedell, J. R., Vannote, R, L. (1985). Developments in Stream Ecosystem Theory. Canada, J.Fish. Aquat. Sci 42, 1045-1055.

Mitchell, B., and Gardner, J. S. (1983). Introduction. Pages 1-4 in River basin management: Canadian experiences. University of Waterloo Department of Geography. Pub No. 20, Waterloo, Ontario

Mitchell, B. (2005). Integrated water resource management, institutional ar- 
rangements and land-use planning. Environment and Planning. A 2005, Vol.37, (s.1335-1352). Erişim tarihi Nisan 16, 2015, http://web.env. auckland.ac.nz/courses/geog320/resources/pdf/water/Mitchell_2005. pdf.

Moglen, G.E., Eltahir, E. A. B., and Bras, R. L (1998). On the sensitivity of drainage density to climate change. Water resources research. Vol.34 (4), (s.855-862).

Moring, J. R., Garman, G. C., Mullen, D. M. (1985). The value of ripirian ones for protecting aquatic systems: General concern and recent studies in Maine. (s.315-319), Tucson, Arizona.

Mutkowski, R. A. (1929). The ecology of trout streams in Yellowstone National Park. Roosevelt Wild Life Annuals 2. (s.151-240).

Nabhan, G. P. (1985). Riparian vegetation and indigenous Southwestern Agriculture: Control of erosion, pests and microclimate. (s.232-236), 1.North American Riparian Konferans1. Tucson, Arizona.

Naiman, R. J. Bilby, R. E., Bisson, P. A. (2000). Riparian ecology and management in the Pacific Coastal Rain Forest, Bioscience. Vol 50 (11), 9961011.

Needham. P. R. (1934). Quatiative studies of stream bottom foods. Trans. American Fishery A Soc., 64, 238-247.

Needham, P. R. (1938). Trout streams. Comstock Publ. Co. Ithaca, N.Y., s. 233.

Odum, H. T. (1974). Environment, Power and Society. Minnesotans for sustainability. Erişim tarihi 0cak 13, 2015, erişim adresi: http://www.mnforsustain.org/energy_ecology_economics_odum_ht_1973.htm.

Pallard, B., Castellarin, A., and Montanari, A. (2009). A look at the links between drainage density and flood statistics. Hydrology and Earth System Sciences. No. 13, (s.1019-1029).

Palmer, M. A., Bernhardt, E. S., Allan, J. D., Lake, P. S., Alexander, G., Brooks, S. Carr, J., Clayton, S., vd. (2005). Standards for ecologically successful river restoration. Institute of Ecology, University of Georgia, USA.

Pervititich, J. (2000). İstanbul in the Insurance Maps of Jacques Pervititich. AXA Oyak, ISBN 975-7306-73-8, (s.46-51).

Platt, R. H. (2006). Urban Watershed Management Sustainability, On Stream at a Time. Vol.48, (4), Heldref Yayınc1lik, http://heldref.org/env.php.

Richard, M. T., and Wood D. B. (1985). The economic value of sportfishing at Lees Ferry, Arizona. 1.North American Riparian Konferans1. (s.219222), Tucson, Arizona.

Rodriguez, Iturbe, I., and Escobar, L. A. (1982). The Dependence of drainage density on climate and geomorphology. Hydrolog, System Sciences. No. 27, (s.129-137).

Rowe, P. B. (1963). Streamflow increases after removing woodland-riparian vegetation from a southern California watershed. Journal of Forestry. Vol. $61,365-370$.

Sauer, V.B., Thomas, J., Stricker, V. A. ve Wilson, K. V. (1983). Flood characteristics of urban watersheds in the United States. Geological Survey Water-Supply. Papper 2207.

Scarr, A. (2014). Restore-Rivers Engaging Supporting and Transferring Knowledge for Restorasyon in Europe. Erişim tarihi Nisan 05, 2014, erişim adresi, http://ec.europa.eu/environment/life/project/Projects/ index.cfm?fuseaction $=$ search.dspPage\&n_proj_id $=3780$

Scott, R. L., Shuttleworth, W. J., Goodrich, D. C., Maddock, T. (2000). The water use of two dominant vegetation communities in a semiarid riparian ecosystem. Agricultural and Forest Meteorology. Vol.105 Issues 1-3, (s.241-256). Tucson, Arizona.

Shelford, V. E. and Eddy, S. (1929). Methods fort the study of stream communities. Ecology: 10: 382-292.

Skinner, Q. D., Smith, M.A., Dodd, J. L., and Rodgers, J. D. (1985). Reclamation of Riparian Zones and Water Law: First in time-First in Right. Riparing ecosystems and their management, reconcilin conflicting uses. (s.374-378). 1st North American Riparian Cenference. Tucson, Arizona.

Stabler, D. F. (1985). Increasing summer flow in small streams through management of riparian areas and adjacent vegetation. A Synthesis 1st the North American Riparian Conference. Tucson, Arizona.
Steiner, F.R. (2001). Planning and Urban Design Standards. "Water" (s.5973). USA.

Stromberg, J. C, Tellman, B. (2009). Ecology and Conservation on San Pedro River. Arizona Universitesi.

Teclaff, L. A., Teclaff, E. (1994). Restoring River and Lake Basin Ecosystems. Natural Resources Journal. Vol: 34, 905-932.

Teclaff, L. A. (1996). Evolution of the River Basin Concept in National and International Water Law. Natural Resources Journal. Vol. 36, No:2, University of New Mexico School of Law.

Teclaff, L. A, Teclaff E. (1996). Restoring River and Lake Basin Ecosystems. Natural Resources Journal. Vol. 34, (s.905-932). Erişim adresi http:// lawschool.unm.edu/nrj/volumes/34/4/06_teclaff_restoring.pdf, erişim tarihi Ocak 23, 2015.

The Trust for public land. ( 2013). 2012 Annual Report, Erişim tarihi, Mart 20, 2013, adresi : https://www.tpl.org/.

Tucker, G. E., and Bras, R. L. (2010). Hillslope processes drainage densty and landscape morphology. Water resources research. Vol. 34, No.10, 2751 2764.

Turner, S. F., and Skibitzke, H. E. (1952). Use of water by phreatophytes in a 2000: foot channel between Granite Reef and Gillespie Dams, Maricopa County, Arizona. Transactions of the American Geophysical Union 33, (s.66-72).

Türkiye Ulusal Rapor ve Eylem Planı (1996). Birleşmiş Milletler İnsan Yerleşimler Konferansı Habitat II. İstanbul.

Türkoğlu, H., Bölen, F., Korça, B. P., Terzi, F. ( 2011). Measuring quality of Life in Istanbul. Investigating Quality of Urban Life. R. Marans, R.J.Stimson (Eds.), London, (s.209-232).

United Nations. (1996). Land Administration Guidelines. Economic Comission for Europe, New York and Geneva.

UN-Habitat. (2013).Un-habitat annual report. 2012, ISBN. 978-92-1132555-3, erișim tarihi Mayıs 2013, 2013, http://unhabitat.org/unhabitat-annual-report-2012/, Nairobi, Kenya.

\section{INTERNET KAYNAKLARI}

Url-1 <http://www.ibb.gov.tr >, erişim tarihi 01.11.2012.

Url-2 <http://www.eclac.org $>$, erişim tarihi 01.11.2012.

Url-3 <https://www.facebook.com/groups/gulayribar/>, alındığ1 tarih: 2012-2014

Url-4 <http://fotogaleri.antoloji.com/eski-istanbul-fotograflari/>, erişim tarihi 2012-2014.

Url-5<http://www.ormansu.gov.tr/osb/haberduyuru/duyurular/12-10-08/ Su_Kanunu_Tasla\%C4\%9F\%C4\%B1_G\%C3\%B6r\%C3\%BC\%C5\% 9Flere_a\%C3\%A7\%C4\%B1ld\%C4\%B1.aspx?sflang=tr $>$, erişim tarihi 03.02.2015.

Url-6 <http://www.un.org >, erişim tarihi 01.11.2012.

Url-7 <http://www.mfa.gov.tr/turkiye_nin-su-politikasi.tr.mfa>, erişim tarihi 05.07.2014.

Url-8 <http://www.mfa.gov.tr/turkiye_nin-su-politikasi.tr.mfa>, erişim tarihi 05.07.2014.

Url-9 <http://mevzuat.basbakanlik.gov.tr/Metin1.Aspx?MevzuatKod $=1.3 .4373 \&$ MevzuatIliski $=0 \&$ sourceXmlSearch $=4373 \&$ Tur $=1 \&$ Terti $\mathrm{p}=38 \mathrm{No}=4373>$, erişim tarihi 10.08.2014.

Url-10 < http://www.bbc.com/turkce/haberler/2015/03/150305_seller_ artacak $>$, erişim tarihi 01.09.2017.

Url-11 < http://www.bbc.com/turkce/haberler/2016/05/160516_sel_uyari $>$, erişim tarihi 18.05.2016.

Url-12 <http://www.wri.org/blog/2015/03/world\%E2\%80\%99s-15-countries-most-people-exposed-river-floods, erişim tarihi 23.11.2017.

Url-13 <http://floods.wri.org/\#/>, erişim tarihi 21.02.2018.

Verniers, G., Peeters A., Hallot, H. ( 2013). Hydromorphological quality and river restoration the WALPHY project' in October 2013. Erişim tarihi Nisan 5, 2014, Belçikahttp://www.reformrivers.eu/news/161

Vörösmarty, C. J., Mcintyre, P. B., Gessner, M. O., Dudgeon, D., Prusevich, A., 
Green, P., ..... Davies, P.M. (2010). Global threats to human security and river biodiversity. (s.555-561), Nature 467.

Weeler, S. (2008). State and Municipal Climate Change Plans. (s.481-496), vol.74, American Planning Associasion. Chicago.

Wenger, S. J., and Fowler, L. (2000). Protecting Stream and River Corridors: Creating Effective Local Riparian Buffer Ordinances. (s.21-27), Carl Vinson Institute of Goverment The University of Georgia.

Wood, P. J., Armitage, P. D. (1997). Biological effects of fine sediment in the lotic environment. Vol. 21 (2), 203-217, Springer, Verlag New York Inc.

Wooding, R. A. (1966). A hydraulic model fort he catchment-stream problem III. Comparison with runoff observation. Journal of Hydrology. Vol. 4, 21-37.

Woods, L.G. (1966). Multiple use management of mountain riparian vegetation. In Vegetation Management on Flood Plans and Riparian lands. Phreatophyte Symp., Pac, Soutwest Inter-Agency Comm.66-3 Meet, Albuquergue. N.Mex.(s.37-43).

Woodyer, K. D., and Brookfield, M. (1966). The land system and its stream net: A Morphometric study of two land systems in semi-arid central Australia, CSIRO. Division of Land Research, 66/5, Australia.

Xia,T., Zhu, W., Xin, P., Li, L. (2010). Assesment of urban stream morphology: an integrated index and modelling system. Environmental Monitoring and Assessment. Vol. 167, Issue 1-4, (s.447-460).

Yazır, R.S. (1984). Görsel Türkiye Ansiklopedisi. 2.Cilt, 4.Cilt. (İstanbulKütahya), Görsel Yayınları, 1984.

Yeang, K. (2006). Ecodesign, a manual for ecological design. Eco Design, Wiley Acedemy.

Yetişkin Kubilay, A. (2010). Maps of İstanbul Haritaları, 1422-1922. Denizler Kitapevi, ISBN 978-9944-264-19-8, İstanbul.

Zhang, H. L., Wang, Y. J., Wang, Y. Q., Li, D. X., and Wang, W. K. (2013). The effect of watershed scale on HEC-HMS calibrated parameters: a case study in the Clear Creek watershed in Iowa, U.S. Hydrology and Earth System Sciences. No. 17, 2735-2745. 